\title{
Botany
}

\section{Patterns of rare moss diversity and distribution in Alberta}

\begin{tabular}{|r|l|}
\hline Journal: & Botany \\
\hline Manuscript ID & cjb-2021-0018.R1 \\
\hline Manuscript Type: & Article \\
\hline Aute Submitted by the & 13-Apr-2021 \\
\hline Complete List of Authors: & $\begin{array}{l}\text { Belland, René; University of Alberta, Renewable Resources } \\
\text { Caners, Richard; Royal Alberta Museum, Botany; University of Alberta, } \\
\text { Renewable Resources }\end{array}$ \\
\hline $\begin{array}{r}\text { Keyword: } \\
\text { consideration in a Special } \\
\text { Issue? : }\end{array}$ & Mosses, Alberta, Rare species, Distribution, Diversity \\
\hline
\end{tabular}

\section{SCHOLARONE ${ }^{m}$ Manuscripts}




\section{Patterns of rare moss diversity and distribution in Alberta}

2 René J. Belland ${ }^{1, *}$ and Richard T. Caners ${ }^{1,2}$

$3{ }^{1}$ Department of Renewable Resources, 751 General Services, University of Alberta, Edmonton, Alberta, Canada T6G 2H1

$4 \quad{ }^{2}$ Royal Alberta Museum, 9810 103a Ave. NW, Edmonton, Alberta, Canada T5J 0G2

$5 \quad *$ Corresponding author; e-mail: rbelland@ualberta.ca

6

7

8 Competing interests: the authors declare there are no competing interests.

10 RJB and RTC developed the study concepts, collated and analyzed the data, and wrote and edited the manuscript. 


\section{ABSTRACT}

Rare moss diversity and distribution patterns are described for the province of Alberta. Multivariate analyses are used to elucidate the distribution patterns of the rare mosses in relation to environmental factors, in comparison with those of the common mosses. Hierarchical clustering of species occurrence among Alberta ecoregions resulted in eleven species groups having similar distributions and four ecoregion groups with similar species composition. Rare and common mosses show comparable distributions at the geographic scale of ecoregions; the analyses did not provide support that rare mosses respond to environment factors differently than common mosses. The rare mosses are more narrowly distributed among the species and ecoregion groups than are common species. The most important environmental variables determining species distributions are mean annual temperature and growing degree days. Other important factors determining moss distribution are mean elevation, annual rainfall, and mountain landscape.

Diversity patterns are shown to vary widely among the ecoregions and to differ between rare and common species. Rare species are especially diverse in the Rocky Mountains, which support $81 \%$ of the province's known rare moss flora and reflect a complex of diverse landscapes for moss colonization. Only $40 \%$ of known rare species in Alberta are found in non-mountainous regions.

Keywords: Mosses, rare species, diversity, distribution, Alberta

\section{INTRODUCTION}

Rare species are an important component of plant biodiversity in many regions and understanding their biological attributes and distribution patterns is often imperative for their conservation and management (Söderström et al. 1992; Gaston 1994; Mouillot et al. 2013; Leitão et al. 2016). Depending on how rarity is defined, rare species may comprise up to 35\% of the flora in many areas (Vitt and Belland 1997; Doubt 2001; Heinlen and Vitt 2003; Newmaster et al. 2005). 
While there are many papers written about diversity patterns and characteristics of rare vascular plants (e.g., Pilgrim et al. 2004) there exists a dearth of literature on bryophytes. Rare bryophyte studies have so far focused on describing patterns and relationships of ecological or biological attributes that predominate in rare species as compared with non-rare species.

Vitt and Belland (1997) were among the investigators to use several attributes of Alberta rare mosses, including taxonomy, morphology, ecology, and distribution to show that rare mosses have distinct patterns as compared to common species. Especially notable were hotspots of rare moss diversity centered in some regions of the Canadian Rocky Mountains (hereafter, Rockies) and distinct habitat affinities among rare species as compared with common ones. Similarly, in studies of national parks in Atlantic Canada, rare mosses had relatively high diversity in certain restricted habitats, but especially cliffs and stream gullies (Belland and Brassard 1988; Belland et al. 1992; Belland and Schofield 1994; Belland 1995). Doubt (2001) also described hotspots of high conservation value (including provincially and locally rare species) with respect to habitat types (streams, cliffs, and wetlands were especially important for rare species) in Waterton Lakes National Park.

Elsewhere globally, relatively very few studies have examined landscape patterns of moss diversity in relation to cooccurrence of mosses and environmental drivers of diversity. Heinlen and Vitt (2003) studied patterns of moss diversity in habitats in Washington State and showed that habitats types such as peatlands, streams, and cliffs in particular, were also most important for rare species. In Belgium, Vanderpoorten and Engels (2003) analyzed soil conditions and landscape features in one province to determine how rare moss species diversity correlated with these. Orbán (1992) compared the life histories of endangered bryophytes in Hungary with the entire flora, finding differences in the proportion of colonists and perennial stayer species. Vellak et al. (2007) analyzed the life history and ecological characters of mosses among three frequency groups from three east European countries to determine possible causes of rarity. Söderström et al. (2007) examined global patterns of liverwort rarity within the Lophoziaceae and Scapaniaceae using correlations with two of Rabinowitz's (1981) parameters of rarity (distribution size and habitat specificity). Most of these studies have focused on habitat, or related environmental factors, to help explain the known 
occurrence of rare mosses, but none has included climatic factors at a regional scale in the analysis of the patterns of rare mosses distribution on landscapes.

More than 20 years have passed since the Vitt and Belland (1997) Alberta study. Since that time the number of occurrences of rare mosses has increased substantially as a result of additional search effort (Figure 1). In addition, the search effort for rare mosses now covers a larger proportion of the province with many new areas inventoried, especially the northern parts of the province.

In this study, we focus on the patterns of distribution of the rare mosses of Alberta. The present study builds on the Vitt and Belland (1997) study by providing further insight into three fundamental questions: 1) What are the distribution and diversity patterns of the rare mosses of Alberta? 2) Are the distribution and diversity patterns of the rare mosses different from those of common mosses? 3) What are the main environmental factors that relate to these patterns?

We conduct the analyses by employing ecoregions as sampling units. Ecoregions are land regions with distinctive climate, physiography, vegetation, soil, water, and fauna (Ecological Stratification Working Group 1996), and are the second level in a national hierarchical system of land classification. Ecoregions belong to ecozones, which are larger units of classification based on plant formation, major physiographic divisions, and soil orders. The major advantage of using ecoregions for analysis is that species are analyzed within a natural landscape context. In comparison, other studies have examined species within polygons bounded by either political boundaries or predetermined grid squares (e.g., Belland 2005; Geffert et al. 2013; Preston et al. 2011, 2013). 

about 1,200 km from north to south, and $600 \mathrm{~km}$ from east to west. It is physiographically and geologically diverse. The eastern and northern portions are dominated by sedimentary plain punctuated by plateaus and highlands and are underlain mainly by calcareous bedrock. The extreme northeast portion of the province is characterized by Canadian Shield rocks of metamorphic origin. The plains vary in elevation gently decreasing from about $800 \mathrm{~m}$ a.s.l. in the west to about $200 \mathrm{~m}$ a.s.l. in the northeast. The Rockies border the western plains along the British Columbia-Alberta border. The mountains rise to elevations greater than 2,000 $\mathrm{m}$ in many places. Although the Alberta Rockies encompass only about $10 \%$ of the land area of the province, they include many landforms (e.g., talus slopes, cliff faces, canyons, outwash, avalanche slopes) and diverse lithologies, many of which (especially siliceous rocks) are infrequent or absent in other regions of the province.

Alberta is characterized by a continental climate and distinct seasonality; summers are hot and winters are cold. Most precipitation falls during the summer months. The wide latitudinal range within the province has resulted in wide mean annual temperature variation from north to south across the province: mean annual temperatures vary from $-5{ }^{\circ} \mathrm{C}$ in northern Alberta to

\section{Floristic and climatic data}

Occurrence data for approximately 47,000 unique Alberta moss specimens (including both rare and common species) from several herbaria (ALTA, CANM, PMAE, UADBG, and UBC; refer to Thiers 2020 for herbarium abbreviations) were used in this analysis. The moss vouchers in these herbaria account for a large proportion of the moss specimens collected in the province. The dataset includes also occurrence records downloaded from the Alberta Biodiversity Monitoring Institute (ABMI species data, 91 https://www.abmi.ca) up to and including records for 2011. Data for subsequent ABMI years were not selected because of the 92 additional work involved in importing, checking, and collating them (data for 2011 and earlier had already been compiled). Post- 
2011 data will make an important contribution to future studies, however. Occurrence data from all sources are compiled into a single database (MerlinSQL Version 1.9.5) maintained by René Belland at the University of Alberta. Rare moss data currently held in the Alberta Conservation Information Management System (ACIMS, Alberta Environment and Parks 2017) originated from the data stored in MerlinSQL and thus was included in the analysis. Occurrence data from sources which cannot be verified with a herbarium voucher were not included in this study. While occurrence data for Alberta mosses is also available for download from several data portals, the records from those databases are mostly duplicates of vouchers already held in the herbaria listed above. While it is likely that some additional occurrences are stored in databases, it is unlikely that their addition to this study's dataset would change the results given the large number of occurrences already being included in the analysis, in combination with the geographic scale of the ecozones.

The baseline list of rare species and their statuses was provided by Alberta Environment and Parks (2017) supplemented with more recent information collected since that time. The status definitions follow those of NatureServe (Master et al. 2012). Although the NatureServe criteria used to assign rank may consider as many as 10 conservation status factors, the information available for many mosses allows for the consideration of only two: occurrences and/or range size. For this study rare species are defined as having a NatureServe status of "S1" (number of occurrences $\leq 5$ and a narrow range) in Alberta but also includes ranks that denote a potentially broader range for a species (e.g., S1S2 or S1S3).

Lists of rare species for each of 25 provincial ecoregions (Figure 2) were compiled into a presence/absence data matrix of species by ecoregion. Common species were included in the analyses to provide a context for comparison with the distribution and diversity of rare species.

In total, 495 species were included in the analysis: 373 common and 122 rare species. There were several additional species in the flora that were not included because of lack of distributional information. 

Sphagnum. Species not included in these lists follow the Flora of North America (Flora of North America Editorial Committee 2007, 115 2014). associated environmental data.

A complete list of the species included in the analysis, including their rarity status, floristic affinity, and ecoregions in which they are found is included in Supplementary Materials.

\section{Analysis}

Distribution patterns. To determine and compare the distribution patterns of rare and common species, a two-way classification of species occurrence across ecoregions was performed using hierarchical clustering implemented in PC-Ord Version 7 (McCune and Mefford 2016). Two-way classification groups species based on their presence within ecoregions (species classification; hereafter distributional elements) and in addition, the ecoregions are classified based on their component species (ecoregion classification; hereafter ecoregion groups). To enable direct comparison of the distribution patterns of the rare and common species, all species were analysed together. For both classifications, we used Jaccard's index of similarity and the flexible $\beta$ group linkage method with a $\beta$ value of -0.05 (i.e., flexible clustering, McCune and Grace 2002). The group membership option was used to help interpret at which level of classification the dendrogram should be interpreted.

131 for interpretation. 
Diversity patterns. Diversity patterns of the rare and common species were evaluated by compiling the numbers of species for each ecoregion and ecozone of the province. Compilations of world floristic affinities (hereafter, floristic affinities) for the common and rare species were also summarized for comparison with the results of Vitt and Belland (1997). World floristic affinities are based on species' associations with global biomes and are characterized by distinct communities of plants and animals and whose distributions are controlled by large scale climate and physiography. Biomes are geographically extensive and typified by the life forms of the dominant organisms, usually the flora and dominant vegetation. We define five general floristic affinities: Arctic, boreal, temperate, montane, and azonal. Boreal, temperate, and Arctic mosses are mostly restricted to the boreal, temperate, and Arctic biomes, respectively. Montane species are restricted to mountain ranges globally, whereas azonal species are widely distribution among several biomes. The representation of floristic affinities in a flora is therefore useful as an indicator of the association of the flora with generalized climate and geography, and in the case of disjuncts, of their possible dispersal history (see for instance Belland 1987).

Distribution breadth. It is expected that rare species have more narrow distributions than common species (Rabinowitz 1981; Gaston 1994). To compare distribution size of rare and common species, we used the number of ecoregions occupied by common and rare species as a measure of species distribution breadth.

Relationships to environmental variables. Relationships between species and the environmental variables that may influence their distributions across Alberta were examined by distance-based redundancy analysis (db-RDA; Legendre and Anderson 1999) in Canoco Version 5.12 (ter Braak and Šmilauer 2012). A presence-absence matrix of 495 mosses across the 25 ecoregions that occur in Alberta was compared to a matrix of 16 climatic and landform coverage variables with measures available at the ecoregion level (Ecological Framework Attribute Data, http://sis.agr.gc.ca/cansis/nsdb/ecostrat/1999report/data_tables.html; Ecological Stratification Working Group 1996). There Ecological Framework Attribute Data (Ecological Stratification Working Group 1996) originally contained a large number of 
potential environmental variables. We derived the reduced set of 16 variables for $\mathrm{db}$-RDA by reviewing and retaining variables that were most likely to be important drivers of moss distributions among ecoregions based on our knowledge. Many variables were considered unimportant for this purpose and were not used. We then examined inter-correlations among the reduced set of variables and retained ones that were the least inter-correlated and deemed to be the most important descriptors of species. Final selected climatic variables were: total annual precipitation, total annual snowfall, total annual rainfall, mean annual temperature, minimum annual temperature, maximum annual temperature, mean elevation, minimum elevation, maximum elevation, and growing degree days above $0^{\circ} \mathrm{C}$. Landform variables represented coverage (square kilometers) within each ecoregion for: plateau, hilland, mountain, plain, scarp, and valley. The following variables were log-transformed as $x^{\prime}=\ln (x)+1$ to maximize normality prior to analysis: total annual precipitation, growing degree days above $0^{\circ} \mathrm{C}$, plateau, hilland, and valley. Forward selection was used to obtain a parsimonious set of variables that explained the greatest amount of variation in moss occurrence among ecoregions. This was performed using Bray-Curtis dissimilarity for species and 9,999 permutations for tests of significance. To assess the importance of each variable in structuring the species data, we present intra-set correlations (Canoco Bip.E scores) and their significance along the first three ordination axes based on Spearman rank-correlations.

Species centroids were plotted within the db-RDA ordination space for axes 1-2 and axes 1-3. The centroids were used to generate maximum-bounded polygons for the species distributional elements and ecoregion groups that resulted from the twoway classification of species and ecoregions. Polygons were also generated for each floristic affinity.

\section{RESULTS AND DISCUSSION}

\section{Diversity patterns within ecozones and ecoregions}

The mean number of species per ecoregion is 116 . However, there is considerable variation in number of species, ranging from 9 (ecoregion 87) to 399 (ecoregion 207) (Table 1). The highest diversities of mosses are in the two ecoregions of the Montane 
Cordillera Ecozone (ecoregions 207 and 214), where each ecoregion has greater than 300 species (approximately 60\% of the total known Alberta moss flora). Overall, but with some exceptions, many of the ecoregions of the Prairies, Taiga, and Boreal Ecozones have significantly fewer species, usually less than 100 , or less than $20 \%$ of the total flora. Exceptions include ecoregions 145 and 147 (Boreal Plains Ecozone), and 156 (Prairies Ecozone), each of which have more than 180 species.

Common mosses represent greater than $90 \%$ of the moss species in most ecoregions (Table 1), and never less than $80 \%$. Their proportion is smallest in ecoregions $156,160,207$, and 214 , but these ecoregions still include greater than $80 \%$ common mosses. Both ecoregions in the Montane Cordillera Ecozone $(207,214)$ each possesses more than 45 rare species $(14 \%$ of the ecoregion flora). Ecoregion 207, especially, is rich in rare mosses, with 73 (18.3\%) species. Two other ecoregions (145 and 156) each possess about 20 rare species (7.8\% and 10.7\%, respectively). One ecoregion (160, Cypress Upland), has a known moss flora of only 39 species and it is unlikely that the high proportion of rare mosses ( 6 mosses or $15.4 \%$ of the ecoregion flora) is a true representation of the composition of the flora.

Most (20 of 25) ecoregions have fewer than 13 rare species; six of these ecoregions (all in the Boreal and Taiga Ecozones, Table 1) have no rare species. Most ecoregions have less than $7 \%$ of their flora represented by rare species, and many have less than $3 \%$.

The patterns shown at the ecozone level reflect those at the ecoregion level (Table 1). The Montane Cordillera Ecozone is by far the richest in moss diversity, encompassing about $90 \%$ of the total moss flora and $22.5 \%$ of the rare species of Alberta. The Prairies Ecozone has about $44 \%$ of the total moss flora and $12 \%$ of the species are rare. Of the Boreal and Taiga Ecozones, the Boreal Plains Ecozone supports the highest species richness with about two-thirds of the Alberta flora, but only about $12 \%$ of the flora is rare species. All other Boreal and Taiga Ecozones are species poor, each containing less than $25 \%$ of the total moss flora and less than $2.5 \%$ of their moss floras are rare species. 
The very low diversity in some ecozones is most certainly attributable to lack of collecting effort in them. This is particularly evident in the Taiga Plains, Taiga Shield, and Boreal Shield Ecozones. Together these support less than $29 \%$ of the total provincial moss flora, whereas the other ecozones individually possess more than $40 \%$ of the flora. Although the Boreal Plains Ecozone has highest diversity among the Boreal and Taiga Ecozones, six (of 13) of the component ecoregions included in this ecozone each possess less than $20 \%$ of the provincial moss flora.

Lack of collecting is undoubtedly also is a key factor explaining the low moss diversity in many of the ecoregions situated within the Prairies Ecozone. Of the five ecoregions within the Prairies Ecozone, only the Aspen Parkland Ecoregion (156) shows substantial species diversity; the remaining four ecoregions have fewer than $15 \%$ of the provincial flora and most possess less than 10\%. This study lists 91 species for the prairies (excluding the Aspen Parkland Ecoregion 156 and Cypress Upland Ecoregion 160) in Alberta. This diversity value is similar to that in Bird (1962) which enumerates only 83 moss species from across the prairies of Manitoba, Saskatchewan, and Alberta. It is clear that few additional species have been documented for the prairies since Bird's (1962) paper appeared nearly 60 years ago.

\section{Distribution breadth}

As expected, common species are broadly distributed across ecoregions with greater than $50 \%$ (147 species) occurring in 5 or more ecoregions (Figure 3). However, a significant proportion of common species, about $24 \%$ or 89 species, also show very narrow distributions and are found in only 1 or 2 ecoregions (e.g., Aulacomnium turgidum, Buxbaumia viridis, Grimmia torquata, Kiaeria byttii, Polytrichastum alpinum). This proportion increases to 37\% (141 species) if species found in 3 ecoregions are included. The narrow distributions of these species are related to the restricted (e.g., alpine) habitats that are not found elsewhere in Alberta. 

only 1 or 2 ecoregions. There are no rare mosses known from more than 9 ecoregions.

Twenty-five rare moss species (20\% of rare mosses) are known from 3 or more ecoregions (Figure 3). Hygroamblystegium tenax and Splachnum rubrum are the most widespread ( 9 ecoregions each) and are represented by numerous occurrences in the ecoregions where they are found. Two species occur at more than 20 sites (Entodon concinnus, Pseudoleskea patens), but most are found at fewer than 10 sites (e.g., Bartramia pomiformis, Grimmia teretinervis, Pohlia bulbifera, Syntrichia caninervis, Zygodon viridissimus).

While rare species are generally narrowly distributed and common species more broadly ranging, the difference between commonness and rarity is not entirely related to size of range because, as noted previously, a substantial proportion of common species also show narrow distributions. However, unlike rare mosses, common mosses with narrow distributions across ecoregions have more occurrences in the ecoregions where they are found than rare species with similar distributions. Thirty-six of the 89 common species that occur in 1 or 2 ecoregions are known from at least 10 or more sites and another 22 species are known from more than 20 sites.

The restricted range of the majority of such common species can most likely be attributed to habitat and dispersal limitations. Most are restricted to the Montane Cordillera Ecozone because of their association with siliceous rock substrate or alpine habitats, neither of which are commonly found elsewhere in Alberta (e.g., Aulacomnium turgidum, Conostomum tetragonum, Encalypa alpina, Grimmia alpestris, Kiaeria starkei, Pogonatum dentatum, Polytrichum sexangulare, Racomitrium lanuginosum, $R$. heterostichum, Ulota curvifolia). Others are species for which little is known about their occurrence and range in the province, or are recently reported to the province: Brachythecium fendleri, Hypnum holmenii, Philonotis yezoana, Schistidium 
confervoides, S. frigidum, Sphagnum isovitae (Doubt 2001; Caners 2011; Alberta Environment and Parks 2017; MerlinSQL Version 1.9.5).

\section{World floristic affinities}

There are considerable differences between the representation of floristic affinities of the rare and common mosses (Figure 4). Boreal mosses dominate the common species and represent almost $60 \%$ of that flora, whereas boreal mosses are only half as important in the rare flora (30.8\%). Species belonging to the temperate affinity represent the largest proportion of rare mosses (34\%). Similarly, montane mosses are an important component of the rare flora (26\%) but represent only $9 \%$ of the common flora. Arctic mosses are slightly more important among common mosses than among the rare species.

These results differ markedly from those presented by Vitt and Belland (1997) where the boreal affinity represented the largest percentage of the rare moss flora (42\%) at the expense of the temperate (27\%) and montane (15\%) affinities. Several factors may explain these differences, including considerable additional collection effort (since 1997) in the Rockies (i.e., ecoregions of the Montane Cordillera Ecozone), extensive revision of the status lists since the Vitt and Belland (1997) study, as well as changes to the NatureServe status ranking process. Regarding the latter, the NatureServe rankings used in this study were based on a combination of range size and number of occurrences (Alberta Environment and Parks 2017), while the rankings used by Vitt and Belland (2007) used only numbers of occurrences. This change resulted in a large number of differences to species rankings and to the composition of the Alberta tracking list itself. For instance, 53 species previously ranked as S1 in 1996, were reevaluated at S2 or at a more common rank in 2015.

The results presented here better reflect the importance of the montane and temperate affinities in the rare moss flora as compared with those presented by Vitt and Belland (1997). Both of these affinities contain species with range extensions into Alberta from wider distributions outside the province. Many of the rare temperate species, for instance, have northern range 
extensions from wider ranges south of the province, usually the Great Plains of the USA. The vast majority of montane species is widely ranging in British Columbia and consists of species with range extensions into the mountains of western Alberta.

\section{Provincial distribution patterns}

\section{Ecoregion classification}

Indicator species analysis dendrogram pruning resulted in an ecoregion classification of four ecoregion groups based on the floristic similarity of component ecoregions (Table 2). Most ecoregions within a group are geographically contiguous or nearly so. With the exception of the Prairies Group, which consists of ecoregions from only one ecozone, the other 3 groups contain ecoregions from two or more ecozones.

The Prairies Group comprises four ecoregions (Table 2) that are all located in the southeastern corner of the province and belong to the Prairies Ecozone. This group possesses the smallest flora (101 species; Figure 5) of the ecoregion groups, of which about $10 \%$ are rare species.

The Central Boreal Group encompasses the largest area of the province, and includes almost half (12) of the Alberta ecoregions (Table 2). All of the included ecoregions are geographically contiguous. The group is diverse in mosses, possessing 248 species or $50 \%$ of the provincial moss flora (Figure 5). About $11 \%$ (27 species) of the group's mosses are rare.

The Northern Boreal Group includes five ecoregions (Table 2). Four of these are in northernmost Alberta where they are geographically separated by one or two narrow ecoregions. They include the ecoregions in the extreme northeast and northwest of the province, as well as the uplands represented by Caribou Hills (ecoregion 67) and an unnamed upland (ecoregion 140) west of Thickwood Hills. The Northern Boreal Group includes also ecoregion 146 (Western Alberta Uplands), an ecoregion found in the 
foothills of southwestern Alberta several hundred kilometers south of the other ecoregions in the group. The Northern Boreal Group contains only about one quarter of the provincial moss flora (26.5\%) and only 5 mosses are rare (Figure 5).

The Mountains \& Foothills Group comprises four ecoregions: two mountainous ecoregions (207, 214), a northern foothills ecoregion (145), and an ecoregion dominated by aspen parkland (156). The former three are geographically contiguous along a broad zone, but the latter ecoregion (156) is contiguous with ecoregion 214 only at its very narrow southwestern extent. This is by far the most floristically diverse ecoregion group, including $97 \%$ (482 species) of the Alberta moss flora and $95 \%$ (116 species) of the provincial rare mosses (Figure 5).

Compared with the other two ecoregion groups, the diversities of both the Northern Boreal and Prairies Groups are low. These groups support only about half the numbers of species as the Central Boreal and Mountains \& Foothills Groups. This is particularly notable when comparing the Northern Boreal with the Central Boreal Groups. It is expected that since the ecoregions in both groups are largely contiguous and their landscapes similar, that the Northern Boreal Group would thus show higher moss diversity and both groups would share a larger proportion of species. The low diversity of the Northern Boreal Group is most likely attributable to a general lack of survey effort in the region.

Lack of survey effort may also explain the low moss diversity of the Prairies Group. The low diversity may be exacerbated by loss of suitable habitat through agricultural land use practices and an overall lower diversity of habitats for mosses. As of 2010 , 70\% of grasslands in the Prairies Ecozone have been lost to agriculture and other human activities (Federal, Provincial and Territorial Governments of Canada 2010) and thus are essentially suitable only for colonization by a few ephemeral or highly disturbance-tolerant species.

Assuming that the Alberta moss flora reflects uniform climatic gradients across the study area, one might expect that geographically contiguous ecoregions would group together in the ecoregion classification. Overall, the classification results support this assumption. The ecoregion classification resulted in two groups (Central Boreal, Prairies) consisting of broadly 
contiguous ecoregions suggesting that their floras are patterned largely by uninterrupted climatic gradients. However, two ecoregion groups (Mountains \& Foothills, Northern Boreal) include ecoregions that are separated by wide distances or that show physiographic inconsistencies with the other ecoregions in the group. For instance, all ecoregions of the Northern Boreal Group show wide geographical gaps between them. With the exception of the Athabasca Plain (ecoregion 87), most ecoregions of the Northern Boreal Group are upland ecoregions with moderate elevation and relief. The vast majority of species in the group are common (126 of 131 species) and most occur in 10 or more ecoregions across the northern regions of the province. The group possesses only 5 rare species and, of these, 4 are restricted to the Western Alberta Upland Ecoregion (ecoregion 146). Although this ecoregion is in the foothills of the Rockies, it has nevertheless been classified as belonging to the Boreal Plains Ecozone.

The Mountains \& Foothills Group includes the Aspen Parkland Ecoregion (156), characterized by a very different physiography than the other three ecoregions in the group. The aspen parkland is an ecotone situated between the southern boreal forest in the north and the prairies to the south. Its inclusion within the Mountains \& Foothills Group is an artifact of the ecoregion classification. While most aspen parkland occurs in the north central portion of the Prairies Ecozone, a small finger of this ecoregion extends into the foothills of southwestern Alberta. Compared with other areas of the Aspen Parkland (156), this foothills extension has been extensively collected and has numerous species restricted to the foothills that are otherwise absent from most of the Aspen Parkland. The extension is considered a distinct separate Natural Subregion (Foothills Parkland) of the aspen parkland in the Alberta Natural Regions classification (Natural Regions Committee 2006) because it is influenced by the Cordilleran climate. Some of the species found in this parkland extension are: Coscinodon cribrosus, Encalypta spathulata, Grimmia montana, G. teretinervis, Jaffueliobryum raui, Myurella tenerrima, Schistidium tenerum, and Seligeria campylopoda. Most of these species are more frequent in the mountain ecoregions and mainly absent from the remainder of the Aspen Parkland Ecoregion in the Prairies Ecozone. 
Floristic affinities of ecoregion groups. Species with a boreal floristic affinity dominate the common moss flora within each of the four ecoregion groups where they number 50 or more species in each group (Figure 6). The Mountains \& Foothills Group and Central Boreal Group have by far the largest number, both exceeding 150 species. The remaining four affinities are represented in the ecoregion groups by fewer than 50 species. Temperate and Arctic mosses in the Mountains \& Foothills Group number almost twice as many species as compared to the numbers in the other three groups.

Rare species with Arctic, boreal, montane, and temperate floristic affinities show their highest numbers in the Mountains \& Foothills ecoregion group, where the diversity of most (except azonal) floristic affinities is the highest of any ecoregion groups (Figure 7). Boreal and temperate species are also well represented among rare mosses in the Central Boreal Group. The Northern Boreal Group is notable in having only two affinities represented in its rare moss flora which no doubt reflects its small rare moss flora (5 species).

The significant high diversity of rare species of most floristic affinities represented in the mountains and foothills is especially noteworthy, and aligns with Vitt and Belland (1997). In addition, the rare montane and Arctic elements are restricted mainly to the mountains and foothills, which further emphasizes the importance of these physiographic regions as drivers of moss diversity in the province.

There is a general lack of temperate species in southern Alberta, a region where high numbers of such species might be expected because of warmer (more temperate) growing conditions as compared to northern or montane areas. A similar observation was made also by Vitt and Belland (1997). As previously stated, the moss flora of the Prairies Ecozone has received little attention by collectors and the under-representation of temperate species may result in part from this lack of survey effort and from the naturally lower diversity of different habitat types in the ecozone. In contrast, high numbers of both common and rare temperate species occur in the Mountains \& Foothills Group whose southern ecoregion mosses have been well documented 
(e.g., Bird 1968; Doubt 2001). Nevertheless, the flora of the Prairie ecoregion group comprises only 101 moss species (Figure 5), of which 10 are rare. Although the number of rare species is small, it is notable that half (5) are temperate species.

\section{Species classification}

Indicator species analysis dendrogram pruning resulted in a species classification of 11 distributional elements comprised of mosses that have similar distributions with respect to ecoregions. Species that are grouped together are assumed to be responding similarly to regional scale climatic factors and geographic or geological factors. The classification and numbers of species in each element are presented in Figure 8 and described briefly below.

Widespread. This group includes species that are generally widespread across Alberta. Most species occur throughout the mountains and foothills and in the boreal forest. However, many are absent or infrequent in the prairies and northwestern Alberta. Boreal Widespread. The majority of species in this distributional element are widely distributed mainly in the boreal and taiga ecozones of the province. A small number are found in the northern mountains and are disjunct to the boreal forest in northeastern Alberta.

Boreal Disjunct. Mosses in this element occur in the mountains where some are frequent; all are disjunct to the mountains from the boreal zones of eastern Alberta. Most species are generally absent from the central and northwest portions of the boreal zone.

Eastern Boreal. Mosses in this distributional element are restricted mainly to the boreal regions of eastern Alberta.

Rockies \& Foothills. This species group includes mosses mainly restricted to and often widespread in the foothills and mountains of western Alberta. Some species show small outliers to the central boreal region. 
Rockies. Mosses in this distributional element are restricted mainly to the Rockies in the province. The group includes species found throughout the mountains, but includes also species that are known from only the northern mountains (usually northern Banff National Park and northward). Several species have outliers to the eastern boreal areas, or to northern Alberta (e.g., Bartramia pomiformis, Hygrohypnum ochraceum, Pohlia drummondii).

Southern Rockies. This distributional element ranges primarily in the southern Alberta mountains (northern Banff to Waterton Lakes National Park) and includes several species that occur as outliers in the Cypress Upland (160) (Fissidens grandifrons, Pterygoneurum ovatum), or northeastern Alberta (Fontinalis antipyretica).

Northern Foothills. Mosses belonging to this distributional element range mostly in the foothills from the Calgary region northwestward toward Grande Cache. Some species have outliers to either the mountains (Dicranella heteromalla, Encalypta intermedia), or to north-central Alberta (Entodon brevisetus, Schistostega pennata).

Aspen Parkland. All species in this element occur in the Aspen Parkland Ecoregion (156) of central Alberta that extends from east-central Alberta to the southwestern foothills west of Calgary. However, about half of the species have outliers to other ecoregions where they occur more frequently, for instance, Aulacomnium androgynum, Encalypta rhaptocarpa, Myurella tenerrima, Scouleria aquatic, and Tortula obtusifolia (see the discussion of ecoregion groups). Grasslands. This distributional element includes mosses found mainly in the grasslands of the Prairies Ecozone (ecoregions 157-160) and several are found also in the Aspen Parkland Ecoregion (156) or the ecoregions of the Montane Cordillera Ecozone $(207,214)$. Numerous species have outliers in the grasslands of the Peace River area (138). Examples of species with this distribution are Brachythecium collinum, Coscinodon calyptratus, Didmodon fallax, Hennediella heimii, and Schistidium rivulare. 
Others. This distributional element possesses only three mosses: Bryum marratii, Hypnum callichroum, and Warnstorfia pseudostraminea. They are known variously from the Rockies, Prairies and the Boreal Ecozones. All are rare species: $W$. pseudostraminea is known from only two ecoregions whereas the other two species are recorded from only one ecoregion each. Their rarity and scattered occurrences without a distinct pattern among several widely differing ecoregions resulted in a distributional element that is undoubtedly an artifact of the classification algorithm.

The numbers of species vary greatly among distributional elements, from 19 in Grasslands to 126 in Rockies (Figure 8). Rockies contains $25 \%$ of the entire provincial moss flora. Three distributional elements (Widespread, Boreal Widespread,

Mountains \& Foothills) have moderate numbers of species, from 10-15\% of the total Alberta flora, while several elements are less diverse, with less than $8 \%$ of the total flora. The latter include Eastern Boreal, Southern Rockies, Northern Foothills, Southern Foothills, and Grasslands elements.

Of the eleven distributional elements, nine include both rare and common mosses. Common mosses are represented in all elements except "Others", whereas rare mosses are absent only from the Widespread element.

Although rare species are represented in most distributional elements, they are important in only two of them (Rockies, Southern Rockies elements; Figure 8), which together include $>60 \%$ of the Alberta rare moss flora. The Rockies element possesses 57 rare species, or nearly half (47\%) of the Alberta rare moss flora. The Southern Rockies element includes 21 rare mosses, or about $17 \%$ of the Alberta rare moss flora. Rare mosses are least important in Widespread, Boreal Widespread, Boreal Disjunct, Eastern Boreal, Grasslands, and Rockies \& Foothills elements. All other elements have fewer than 11 rare mosses, with half having 5 or fewer. 
While common species predominate in most distributional elements, the ratio of rare to common species in the elements varies considerably (Figure 9). Three elements show high ratios: Northern Foothills, Rockies, and Southern Rockies. Notably, in the Southern Rockies element, there are nearly twice as many rare species as common species.

Several studies have shown a significant positive correlation between numbers of microhabitats/habitats present in an area and diversity of moss species (Vitt et al. 1995; Doubt 2001; Heinlen and Vitt 2003; Newmaster et al. 2005; Cole et al. 2008). Vitt and Belland (1997) hypothesized that both the numbers of microhabitats in a habitat, as well as the types of microhabitats present, are important determinants of rare moss diversity in a landscape. The myriad combinations of diverse geological substrates, climatic conditions, topography and physiography in the mountains creates unique habitats (and microhabitats) that are absent from most other Alberta landscapes. Examples of unique habitats include all the high elevation habitats of the alpine zone (snowbeds, cold rock barrens, alpine meadows), and habitats (cliffs and gorges) made of siliceous rock, a substrate that is otherwise also restricted to the Canadian Shield in northeastern Alberta (ecoregion 69). Both the relatively high diversity of rare mosses and the high ratios of rare to common species across the mountain and foothill distributional elements no doubt reflect the relatively high diversity of suitable habitats and microhabitats for rare species in those regions.

Floristic affinities of distributional elements. The proportion and dominance of floristic affinities within the distributional elements reflect the geographic distribution and position of the distributional elements within Alberta. Azonal species, which are globally widespread, are most numerous in the Widespread and Boreal Widespread elements (Table 3). The wider ranging distributional elements, especially the Widespread, Widespread Boreal, Disjunct Boreal, and Rockies \& Foothills elements, are dominated by wide ranging northern floristic affinities, but especially the boreal affinity. Mosses with a boreal affinity are also conspicuous in the Rockies distributional element. Temperate species are most diverse in the distributional elements of southern Alberta including the Southern Rockies, Aspen Parkland, and Grasslands elements, while Arctic and montane species are restricted to the mountains where they are most diverse in the Rockies and Rockies \& Foothills elements. 
Rare and common species show generally similar patterns of floristic affinity when comparing their numbers within distributional elements (Table 3). Common species are more diverse than rare species within most affinities. There are exceptions, however. For instance, temperate rare species are three times more numerous than common ones in the Southern Rockies element. Similarly both temperate and montane rare species outnumber common species in the Rockies element.

\section{Ordination and distribution group relationships to environmental variables}

Forward selection returned seven variables that were significant descriptors of species data at the ecoregion level (highest to lowest weights along db-RDA axis 1 ): growing degree days above $0^{\circ} \mathrm{C}$, mean annual temperature, mean elevation, mountain landscape cover, total annual rainfall, plains landscape cover, and total annual snowfall. Pseudo-canonical correlations are high for the first three db-RDA axes (Table 4), indicating that the environmental variables chosen for the analysis were effective in explaining the data extracted by the ordination (ter Braak 1986; Lepš and Šmilauer 2003). The first two axes explain the largest proportion of explained variation in the dataset, almost $72 \%$, and the third axis adds an additional $16 \%$. Including the fourth axis (not shown) adds only an additional $5.6 \%$ of explained variation in the dataset and will not be discussed further.

Forward selection resulted in seven environmental variables explaining almost as much of the variation in the dataset as the 25 variables that were tested: total annual snowfall (snow), total annual rainfall (rain), mean annual temperature (MAT), mean elevation (elevation), growing degree days above $0^{\circ} \mathrm{C}(\mathrm{GDDO})$, mountain landscape (mountain), and plains landscape (plains). The Monte Carlo permutation test on all axes was highly significant (pseudo-F $=2.4, P=0.002$ ).

Based on the intra-set correlations with these variables, the first and most important ordination axis is defined by mean annual temperature and growing degree days (Table 5). Both variables are positively correlated with the first axis. A third variable, mean elevation, is also significantly correlated with the first axis, although more weakly than the former two. The second ordination axis is defined by annual rainfall and mountain landscape, both of which are highly positively correlated with this axis. 
Although four environmental variables are significantly positively correlated with the third axis, only two show high correlations.

They are the landform variables mountain landscape and plains landscape; they show positive and negative correlations,

respectively.

The ecoregion db-RDA biplot for the first two axes (Figure 10) shows, with exceptions, that most ecoregions within each of the four ecoregions groups (Table 2) are located in close proximity to one another on the ordination, indicating similarity in their environmental characteristics and species composition. This is especially true of ecoregions belonging to the Central Boreal Group. All ecoregions in this group show a cluster near the centre of the ordination where they are associated with moderate values of the most important environmental variable defining the axes. The Prairie Group ecoregions also show a distinct cluster separated from other ecoregions along the first axis where they are associated with the highest values of both growing degree days and mean annual temperatures. Both remaining ecoregion groups (Northern Boreal, Mountains \& Foothills) have some ecoregions associated with high or low values of some environmental variables, while the other ecoregions belonging to these groups are found intermixed with Central Boreal ecoregions. For instance, the Mountains \& Foothills Group contains two ecoregions (207, 214) that are positioned near the maximum values of annual rainfall and mountains environmental vectors. This is expected since both ecoregions are dominated by mountains situated along the backbone of the wet Continental Divide. However, the remaining two ecoregions in the group $(145,156)$ are clustered with Central Boreal ecoregions in the centre of the ordination. We interpret this to signify that species in these latter ecoregions have broader environmental requirements than many of the species found in ecoregions 207 and 214.

The Northern Boreal ecoregion group presents a similar pattern to that presented by the Mountains \& Foothills Group with some ecoregions intermixed with those of the Central Boreal Group. Of the five ecoregions in this group, three $(65,67,87)$ are associated with low values of mean annual temperature, growing degree days, and mean elevation along the first axis. All three ecoregions are located in northernmost Alberta. The remaining two ecoregions $(140,146)$ are intermixed with the Central Boreal 
ecoregions on the ordination. Both of these ecoregions are found far south of the other three Central Boreal ecoregions within the province. Ecoregion 140 in particular, is dominated by a foothills landscape in southwest Alberta.

The ecoregions db-RDA ordination for axes 1 and 3 (Figure 11) shows a similar pattern of ecoregion placement as axes 1 and 2 (Figure 10). However, the influence of the mountain and plains landscape variables that define axis 3 is evident and shows a clear separation between the high elevations of two Rockies \& Foothills ecoregions $(207,214)$ from those of the lower elevation plain landform. The positioning of Northern Boreal ecoregions 65 and 67 near the end of the mean annual snowfall vector is likely related to having moderate values for mean elevation rather than high values of snowfall. In Figure 10 (axes 1 and 2 ), these same ecoregions show low-moderate values of annual snowfall.

Interrupted climatic gradients have resulted in complex ordinations and this complexity can be attributed to the presence of upland regions in some ecoregion groups, such as the Caribou Hills (ecoregion 67), Thickwood Hills and Birch Mountains (ecoregion 142), Marten Mountain (ecoregion 144) of the Northern Boreal ecoregion group, and Swan Hills (ecoregion 145) of the Rockies \& Foothills ecoregion group. These ecoregions do not represent the climatic environment of the lower elevation ecoregions surrounding them. The effect of these interrupted gradients are seen especially in the Northern Boreal ecoregions where each ecoregion is geographically separated from the other ecoregions in the group, yet the ecoregions share large proportions of their moss floras.

The interrupted climate gradients are reflected also in the distributions of some mosses in the Northern Boreal and Rockies \& Foothills ecoregion groups. Species in these groups often show disjunctions from the Rockies or Foothills to boreal areas. For instance, Oligotrichum hercynicum shows a disjunction to the Swan Hills from its main distribution in the mountains. Others also show disjunctions from a main center of distribution in the mountains but to boreal upland areas: Hygrohypnum smithii, Hypnum revolutum, Pohlia drummondii, and $P$. proligera. 
The species db-RDA ordination for axis 1 and 2 of rare and common mosses is shown in Figure 12. Both common and rare species are broadly distributed across the ordination with the large majority found in the upper half of the ordination where the species are associated with low values of mean annual temperature and growing degree days on axis 1 and high values of total annual rainfall and mountain landscape on axis 2 . Although many species are clustered at high values near the tip of the total annual snowfall vector, this variable is not a significant environmental factor defining either axis and is only weakly correlated with axis 3 (Table 5 ).

Rare species occupy smaller ordination space than common species (Figure 12) suggesting that they are more limited by the environmental factors defining the ordinations than are common species. As shown elsewhere in this study, the large majority of rare species are found in the mountains, which are generally cooler and have higher rainfall than most other areas of the province. These conditions are characteristic of the Continental Divide region in the mountains along the British Columbia-Alberta border. This area has been shown to harbor a diversity of rare silicolous species that are otherwise frequent in the cool, wet climates of adjacent British Columbia (Belland 2011). Furthermore, it is noteworthy that almost all species are positioned in the upper half of the ordination and also concentrated on the left side of the ordination (Figure 11). While this might suggest that species are not associated with any of the ecoregions that fall in the lower half of the ordinations (see Figure 9), the output demonstrates that many rare species are associated with the combinations of environmental variables in define that portion of the ordination space.

\section{CONCLUSIONS}

This work compared rare and common species based only on their distribution and diversity patterns in Alberta. While this study focused on the rare species, the analyses included the Alberta common mosses for comparison and context. We expected that rare species might reveal different or unique distributions compared with common mosses. The results of this study show that 
rare mosses share the large scale distributions in Alberta with common mosses and suggest that rare mosses in Alberta are limited by same large scale environmental factors as common mosses, at least at the regional scale. Similar results are noted in the Gulf of St. Lawrence region by Belland (2005).

Nevertheless, the rare mosses possess distinct distribution characteristics and diversity patterns in the province. Despite having distributions similar to those of common mosses, rare mosses show generally more restricted occurrence within distributional elements than common mosses.

Distinct differences in diversity patterns between rare and common Alberta mosses are especially evident among ecoregions. Whereas common mosses consistently outnumber common ones in all ecoregions, rare moss diversity is relatively high (>10\%) in only a few ecoregions.

Noteworthy is the increased diversity of rare species relative to common species in mountainous ecoregions. While mountains possess by far the most diverse moss floras for both common and rare species, rare species represent a higher proportion of the diversity of the mountain flora than in other parts of the province. Of the 122 rare mosses in Alberta, 99 can be found in the mountains, and of these, 73 are restricted to the Montane Cordillera Ecozone. Almost half of these (31 species) have either montane or Arctic floristic affinities and are not likely to occur elsewhere. By comparison, only 49 rare mosses occur in all the other ecozones of the province combined, and of these only 16 are unique to the ecoregions outside the mountains. The disproportionate number of rare mosses in the mountains is probably best explained by the availability of a wide diversity of habitats with unique sets of microhabitats found in mountains that are absent from the boreal forest or prairies.

The db-RDA ordination analysis did not provide support that common and rare mosses were limited by different environmental factors. The ordination displayed significant overlap in positioning of rare and common species when constrained by the most important environmental variables. This result is not unexpected at the geographic scale used in this study. The same 
environmental values associated with an ecoregion were assigned to all species, whether common or rare, regardless of the particular habitats in which they occurred. However, the ordinations were able to detect the more restricted distributions of rare species compared to common species. We conclude that rare and common species are limited by similar environmental factors, at regional scales at least. If rare species had distinct distribution patterns at this scale, there is no doubt that unique environmental factors would account for these and the differences would have appeared on the ordinations.

This is one of the first studies of which we are aware to examine rare plants distributions using ecoregions as sampling units (see also Locky and Bayley 2010). While the results were meaningful and interpretable, some of the results were surprising. For instance, the Aspen Parkland Ecoregion (156) was classified with Mountains \& Foothills Group ecoregions based on the presence of several species restricted to a small portion of the Aspen Parkland Ecoregion. Additionally, only two Cordilleran ecoregions were used in the analysis. These ecoregions proved to be highly diverse for both the rare and common components of the flora, which reflects a complex of diverse landscapes for moss colonization. Teasing more detailed diversity patterns from these ecoregions may have benefited from the use of a finer-scale habitat classification, such as that provided by the Natural Subregions of Alberta (Natural Regions Committee 2006) or the ecodistricts found within ecoregions (Ecological Stratification Working Group 1996).

Comparison of biological attributes that might contribute to an understanding of rarity were not considered in this study of Alberta rare mosses as they were by Vitt and Belland (1997). That study showed marked differences in morphological characters and life history attributes of rare mosses in Alberta as compared to the common species. In particular, rare mosses were mainly acrocarps, stress tolerators, and perennials. A comparison of life history characters of common and rare species that have similar or differing regional distributions as presented in this study would no doubt yield valuable insight into dispersal and habitat limitations of the Alberta rare mosses. 


\section{REFERENCES}

528

Alberta Environment and Parks. 2017. List of all non-vascular plant taxa in the ACIMS database. Available from http://www.albertaparks.ca/albertaparksca/management-land-use/alberta-conservation-information-managementsystem-acims/tracking-watch-lists/ [Accessed 22 September 2020].

Anderson, L.E. 1990. A Checklist of Sphagnum in North America North of Mexico. The Bryologist 93: 500-501.

Anderson, L.E., Crum, H.A., and W.R. Buck. 1990. List of Mosses of North America North of Mexico. The Bryologist 93: $448-499$.

Belland, R.J. 1995. The bryophytes of Prince Edward Island National Park, Canada: affinities, habitats, and diversity. Fragm. Flor. Geobot. 40: 349-364.

Belland, R.J. 1987. The moss flora of the Gulf of St. Lawrence region: ecology and phytogeography. J. Hattori Bot. Lab. 62: $205-267$.

Belland, R.J. 2005. A multivariate study of moss distributions in relation to environment in the Gulf of St. Lawrence region, Canada. Can. J. Bot. 83: 243-263.

Belland, R.J. 2011. Rare mosses from siliceous regions in the Northern Rockies, Alberta, Canada: additions and significance. Davidsonia 21: 3-23.

Belland, R.J., and Schofield, W.B. 1994. The ecology and phytogeography of the bryophytes of Cape Breton Highlands National Park, Canada. Nova Hedwigia: 59: 275-310.

Belland, R.J., Schofield, W.B., and Hedderson, T.A. 1992. Bryophytes of the Mingan Archipelago National Park Reserve, Québec: a boreal flora with arctic and alpine components. Can. J. Bot. 70: 2207-2222. 
Belland, R.J., and Brassard, G.R. 1988. The bryophytes of Gros Morne National Park, Newfoundland, Canada: ecology and phytogeography. Lindbergia 14: 97-118.

Bird, C.D. 1962. Mosses of the prairies of west-central Alberta. Can. J. Bot. 40: 35-47.

Bird, C.D. 1968. New or otherwise interesting mosses in Alberta. Bryologist 71: 358-361.

Birks, H.J.B., Heegaard, E., Birks, H.H., and Jonsgard, B. 1998. Quantifying bryophyte-environment relationships. In Bryology for the twenty-first century. Edited by Bates, N.W. Ashton and J.G. Duckett. Maney and the British Bryological Society, Leeds, UK. pp. 305-319.

Callaghan, D.E., and Ashton, P.A. 2008. Attributes of rarity in a regional bryophyte assemblage. J. Bryol. 30: $101-107$.

Caners, R.T. 2011. Major northern range extension of Brachythecium fendleri (Sull.) A.Jaeger in North America into the southern Canadian Rocky Mountains. Evansia 28: 104-106.

Cole, H.A., Newmaster, S.G., Bell, F.W., Pitt, D., and Stinson, A. 2008. Influence of microhabitat on bryophyte diversity in Ontario mixedwood boreal forest. Can. J. For. Res. 38: 1867-1876.

Doubt, J.C. 2001. Distribution patterns of moss conservation value with implications for conservation management: a case study of Waterton Lakes National Park. M.Sc. thesis. Department of Biological Sciences, University of Alberta, Edmonton.

Dufrêne, M., and Legendre, P. 1997. Species assemblages and indicator species: the need for a flexible asymmetrical approach. Ecol. Monogr. 67: 345-366.

Ecological Stratification Working Group. 1996. A national ecological framework for Canada. Agriculture and Agri-Food Canada, Research Branch, Centre for Land and Biological Resources Research, Ottawa and Environment Canada, State of the Environment Directorate, Ecozone Analysis Branch, Ottawa. 
Federal, Provincial and Territorial Governments of Canada. 2010. Canadian biodiversity: ecosystem status and trends 2010. Canadian Councils of Resource Ministers, Ottawa.

Flora of North America Editorial Committee [FNAEC] (eds.). 2007. Flora of North America North of Mexico. Volume 27. Bryophyta, part 1. New York: Oxford University Press.

Flora of North America Editorial Committee [FNAEC] (eds.). 2014. Flora of North America North of Mexico. Volume 28. Bryophyta, part 2. New York: Oxford University Press.

Gaston, K.J. 1994. Rarity. Chapman and Hall, London, UK.

Geffert, J.L., Frahm, J-P., Barthlott, W., and Mutke, J. 2013. Global moss diversity: spatial and taxonomic patterns of species richness. J. Bryol. 35: 1-11.

Heinlen, E.R., and Vitt, D.H. 2003. Patterns of rarity in mosses of the Okanogan Highlands of Washington State: an emerging coarse filter approach to rare moss conservation. Bryologist 106: 34-52.

Legendre, P., and Anderson, M.J. 1999. Distance-based redundancy analysis: testing multispecies responses in multifactorial ecological experiments. Ecol. Monogr. 69: 1-24.

Leitão, R.P., Zuanon, J., Villéger, S., Williams, S.E., Baraloto, C., Fortunel, C., Mendonça, F.P., and Mouillot, D. 2016. Rare species contribute disproportionately to the functional structure of species assemblages. Proc. Roy. Soc. B 283: 20160084.

Lepš, J., and Šmilauer, P. 2003. Multivariate analysis of ecological data using CANOCO. Cambridge University Press, Cambridge, UK.

Locky, D.A., and Bayley, S.E. 2010. Plant diversity in wooded moderate-rich fens across boreal western Canada: An ecoregional perspective. Biodiversity and Conservation 19: 3525-3543. 
McCune, B., and Grace, J.B. 2002. Analysis of ecological communities. MjM Software, Gleneden Beach, Oregon.

McCune, B., and Mefford, M.J. 2016. PC-ORD. Multivariate analysis of ecological data. Version 7. MjM Software, Gleneden Beach, Oregon.

Master, L.L., Faber-Langendoen, D., Bittman, R., Hammerson, G.A., Heidel, B., Ramsay, L., Snow, K., Teucher, A., and Tomaino, A. 2012. NatureServe Conservation Status Assessments: Factors for Evaluating Species and Ecosystem Risk. NatureServe, Arlington, Virginia.

Mouillot, D., Bellwood, D.R., Baraloto, C., Chave, J., Galzin, R., Harmelin-Vivien, M., Kulbicki, M., Lavergne, S., Lavorel, S., Mouquet, N., Paine, T., Renaud, J., and Thuiller, W. 2013. Rare species support vulnerable functions in high-diversity ecosystems. PLoS Biol. 11: e1001569.

Natural Regions Committee. 2006. Natural regions and subregions of Alberta. Compiled by D.J. Downing and W.W. Pettapiece. Government of Alberta, Edmonton, Alberta. Pub. No. T/852.

Newmaster, S.G., Belland, R.J., Arsenault, A., Vitt, D.H., and Stephens, T.A. 2005. The ones we left behind: comparing plot sampling and floristic habitat sampling for estimating bryophyte diversity. Divers. Distrib. 11: 57-72.

Orbán, S. 1992. Life strategies in endangered bryophytes in Hungary. Ecol. Conserv. 59: 109-111.

Pilgrim, E.S., Crawley, M.J., and Dolphin, K. 2004. Patterns of rarity in the native British flora. Biol. Conserv. 120: 161-170.

Preston, C.D., Harrower, C.A., and Hill, M.O. 2011. Distribution patterns in British and Irish liverworts and hornworts. J. Bryol. 33: 3-16.

Preston, C.D., Harrower C.A., and Hill, M.O. 2013. A comparison of distribution patterns in British and Irish mosses and liverworts. J. Bryol. 35: 71-87. 
Rabinowitz, D. 1981. Seven forms of rarity. In The biological aspects of rare plant conservation. Edited by H. Synge, Wiley, New York. pp 205-217.

Söderström, L., Hallingback, T., Gustafsson, L., Cronberg, N., and Hedenas, L. 1992. Bryophyte conservation for the future. Biol. Conserv. 59: 265-270.

Söderström, L, Séneca, A., and Santos, M. 2007. Rarity patterns in members of the Lophoiziaceae/Scapaniaceae complex occurring north of the Tropics - implications for conservation. Biol. Conserv. 135: 352-359.

ter Braak, C.J.F. 1986. Canonical correspondence analysis: a new eigenvector technique for multivariate direct gradient analysis. Ecology 67: 1167-1179.

ter Braak, C.J.F., and Šmilauer P. 2012. Canoco reference manual and user's guide: software for ordination (Version 5.0). Microcomputer Power, Ithaca, New York.

Thiers, B. 2020. Index Herbariorum: a global directory of public herbaria and associated staff. New York Botanical Garden's Virtual Herbarium. Available from http://sweetgum.nybg.org/science/ih/ [Accessed 22 September 2020].

Vanderpoorten, A., and Engels, P. 2003. Patterns of bryophyte diversity and rarity at a regional scale. Biodivers. Conserv. 12: 545553.

Vellak, K., Vellak, A., and Ingerpuu, N. 2007. Reasons for moss rarity: study in three neighbouring countries. Biol. Cons. 135: 360368.

Vitt, D.H., and Belland, R.J. 1997. Attributes of rarity among Alberta mosses: patterns and prediction of species diversity. Bryologist 100: 1-12. 
618 Vitt, D.H., Li, Y., and Belland, R.J. 1995. Patterns of bryophyte diversity in peatlands of continental western Canada. Bryologist 98: 218-227. 
2 Table 1. Moss species diversity in the ecozones and ecoregions of Alberta. Numbers are number of species. Numbers in

3 parentheses are percentage of the flora for an ecoregion.

4 Table 2. Classification of the ecoregions of Alberta based on species presence.

5 Table 3. Percentages of species within floristic affinities for each of the species distributional elements.

6 Table 4. Summary of the results of the db-RDA of Alberta moss distributions and environmental variables.

7 Table 5. Db-RDA intra-set correlations of environmental variables and ordination axes. Names in parentheses following each 8 variable are the abbreviations used in db-RDA Figures 9 and 10. Single asterisks indicate significance at $p<0.05$; two asterisks 9 indicate significance at $p<0.01$; three asterisks indicate significance at $p<0.001$. 
Table 1. Moss species diversity in the ecozones and ecoregions of Alberta. Numbers are number of species. Numbers in parentheses are percentage of the flora for an ecoregion.

\begin{tabular}{|c|c|c|c|c|c|c|}
\hline $\begin{array}{c}\text { Ecoregion } \\
\#\end{array}$ & Ecoregion name & $\begin{array}{l}\text { Alberta } \\
\text { area (km } \\
\text { sq) }\end{array}$ & $\begin{array}{c}\text { Total \# of } \\
\text { species }\end{array}$ & $\begin{array}{c}\% \text { of } \\
\text { Alberta } \\
\text { flora }\end{array}$ & Common & Rare \\
\hline \multicolumn{7}{|c|}{ Taiga Plains Ecozone } \\
\hline 64 & Hay River Lowland & 37705.3 & 70 & 14.1 & 70 (100.0) & $0(0.0)$ \\
\hline 65 & Northern Alberta Uplands & 10926.8 & 16 & 3.2 & $16(100.0)$ & $0(0.0)$ \\
\hline 67 & Northern Alberta Uplands & 13806.4 & 64 & 12.9 & $63(98.4)$ & $1(1.6)$ \\
\hline Ecozone: & & 62438.5 & 97 & 19.6 & $96(98.9)$ & $1(1.1)$ \\
\hline \multicolumn{7}{|c|}{ Taiga Shield Ecozone } \\
\hline 69 & Tazin Lake Upland & 9284.2 & 120 & 24.2 & 117 (97.5) & $3(2.5)$ \\
\hline Ecozone: & & 9284.2 & 120 & 24.2 & $117(97.5)$ & $3(2.5)$ \\
\hline
\end{tabular}

\begin{tabular}{clccccc}
\multicolumn{7}{c}{ Boreal Shield Ecozone } \\
87 & Athabasca Plain & 6427.6 & 9 & 1.8 & $9(100)$. & $0(0.0)$ \\
\hline Ecozone: & & 6427.6 & 9 & 1.8 & $9(100)$. & $0(0.0)$ \\
& & & & & & \\
& & & & \\
136 & Slave River Lowland & 34825.3 & 138 & 27.9 & $130(94.2)$ & $8(5.8)$ \\
137 & Clear Hills Upland & 23497.9 & 67 & 13.5 & $67(100.0$ & $0(0.0)$ \\
138 & Peace Lowland & 60181.4 & 106 & 21.4 & $103(97.2)$ & $3(2.8)$ \\
139 & Mid-Boreal Uplands & 8327.5 & 71 & 14.3 & $71(100.0$ & $0(0.0)$ \\
140 & Mid-Boreal Uplands & 3322.8 & 23 & 4.6 & $23(100.0$ & $0(0.0)$ \\
141 & Mid-Boreal Uplands & 12240.1 & 78 & 15.8 & $76(97.4)$ & $2(2.6)$
\end{tabular}




\begin{tabular}{llccccc}
142 & Wabasca Lowland & 51635.9 & 134 & 27.1 & $130(97.0)$ & $4(3.0)$ \\
143 & Western Boreal & 11395.0 & 73 & 14.7 & $72(98.6)$ & $1(1.60$ \\
144 & Mid-Boreal Uplands & 25610.0 & 128 & 25.9 & $123(96.1)$ & $5(3.9)$ \\
145 & Western Alberta Upland & 66909.6 & 258 & 52.1 & $238(92.2)$ & $20(7.8)$ \\
146 & Western Alberta Upland & 1640.1 & 88 & 17.8 & $84(95.5)$ & $4(4.5)$ \\
147 & Mid-Boreal Uplands & 38598.8 & 181 & 36.6 & $168(92.8)$ & $13(7.2)$ \\
149 & Boreal Transition & 43669.8 & 165 & 33.3 & $153(92.7)$ & $12(7.3)$ \\
\hline Ecozone: & & 381854.1 & 320 & 64.6 & $282(98.1)$ & $38(11.9)$
\end{tabular}

\begin{tabular}{clccccc} 
& & \multicolumn{2}{c}{ Prairies Ecozone } & & & \\
156 & Aspen Parkland & 59110.8 & 196 & 39.6 & $175(89.3)$ & $21(10.7)$ \\
157 & Moist Mixed Grassland & 31698.4 & 49 & 9.9 & $48(97.9)$ & $1(2.1)$ \\
158 & Fescue Grassland & 14916.4 & 66 & 13.3 & $62(93.9)$ & $4(6.1)$ \\
159 & Mixed Grassland & 47086.6 & 43 & 8.7 & $41(95.3)$ & $2(4.7)$ \\
160 & Cypress Upland & 3497.7 & 39 & 7.9 & $33(84.6)$ & $6(15.4)$ \\
\hline Ecozone: & & 156309.9 & 216 & 43.6 & $191(88.4)$ & $25(11.6)$
\end{tabular}

\begin{tabular}{clrcccc}
\multicolumn{7}{c}{ Montane Cordillera Ecozone } \\
207 & $\begin{array}{l}\text { Eastern Continental } \\
\text { Ranges }\end{array}$ & 37185.9 & 399 & 80.6 & $326(81.7)$ & $73(18.3)$ \\
$\begin{array}{l}\text { Northern Continental } \\
\text { Divide }\end{array}$ & 9619.3 & 322 & 65.1 & $276(85.7)$ & $46(14.3)$ \\
\hline Ecozone: & 46805.2 & 444 & 89.7 & $344(77.5)$ & $100(22.5)$
\end{tabular}

15 
Table 2. Classification of the ecoregions of Alberta based on species presence.

18

\begin{tabular}{|c|c|c|c|c|}
\hline $\begin{array}{l}\text { Ecoregion } \\
\text { group }\end{array}$ & $\begin{array}{c}\text { \# of } \\
\text { ecoregions }\end{array}$ & $\begin{array}{l}\text { Ecoregions } \\
\text { included }\end{array}$ & $\begin{array}{l}\text { Ecoregion group } \\
\text { description }\end{array}$ & $\begin{array}{c}\text { Total \# of } \\
\text { species }\end{array}$ \\
\hline $\begin{array}{l}\text { Prairies } \\
\text { Group }\end{array}$ & 4 & 157-160 & $\begin{array}{l}\text { Includes ecoregions from } \\
\text { the Prairies Ecozone only } \\
\text { (but excluding the Aspen } \\
\text { Parkland Ecoregion - see } \\
\text { Mountains \& Foothills } \\
\text { Group) }\end{array}$ & 101 \\
\hline $\begin{array}{l}\text { Northern } \\
\text { Boreal } \\
\text { Group }\end{array}$ & 5 & $\begin{array}{c}65,67,87 \\
140,146\end{array}$ & $\begin{array}{l}\text { Includes ecoregions from } \\
\text { the Boreal Plains, Taiga } \\
\text { Plains, and Taiga Shield } \\
\text { Ecozones. }\end{array}$ & 131 \\
\hline $\begin{array}{l}\text { Mountains } \\
\text { \& Foothills } \\
\text { Group }\end{array}$ & 4 & $\begin{array}{c}145,156,207 \\
214\end{array}$ & $\begin{array}{l}\text { Mainly the mountains and } \\
\text { foothills. Includes } \\
\text { ecoregions from the } \\
\text { Montane Cordillera } \\
\text { Ecozone, but includes a } \\
\text { single ecoregion from the } \\
\text { Prairies Ecozone (Aspen } \\
\text { Parkland Ecoregion) and } \\
\text { the Boreal Plains Ecozone } \\
\text { (Western Alberta Uplands } \\
\text { Ecoregion). }\end{array}$ & 482 \\
\hline $\begin{array}{l}\text { Central } \\
\text { Boreal }\end{array}$ & 12 & $\begin{array}{r}64,69,136- \\
139,141-144,\end{array}$ & $\begin{array}{l}\text { Includes mainly ecoregions } \\
\text { from the Boreal Plains }\end{array}$ & 248 \\
\hline
\end{tabular}




\begin{tabular}{|l|l|l|l|l|}
\hline Group & 147,149 & $\begin{array}{l}\text { Ecozone, but also one } \\
\text { ecoregion from each of the } \\
\text { Taiga Plains and Taiga } \\
\text { Shield Ecozones. }\end{array}$ & \\
\hline
\end{tabular}

19 
Table 3. Percentages of species within floristic affinities for each of the species distributional elements.

\begin{tabular}{|l|c|c|c|c|c|c|c|c|c|c|}
\hline & \multicolumn{2}{|c|}{ Azonal } & \multicolumn{2}{c|}{ Arctic } & \multicolumn{2}{c|}{ Boreal } & \multicolumn{2}{c|}{ Montane } & \multicolumn{2}{c|}{ Temperate } \\
\hline & Common & Rare & Common & Rare & Common & Rare & Common & Rare & Common & Rare \\
\hline Widespread & 13.3 & 0 & 2.4 & 0 & 81.9 & 0 & 0 & 0 & 2.4 & 0 \\
\hline Boreal Widespread & 6.2 & 0 & 7.4 & 0 & 60.5 & 8.6 & 1.2 & 0 & 11.1 & 4.9 \\
\hline Boreal Disjunct & 2.9 & 2.9 & 5.7 & 2.9 & 68.6 & 5.7 & 0 & 0 & 8.6 & 2.9 \\
\hline Eastern Boreal & 0 & 0 & 0 & 0 & 44.4 & 11.1 & 11.1 & 0 & 11.1 & 22.2 \\
\hline Rockies \& Foothills & 0 & 0 & 26.3 & 0 & 43.4 & 1.3 & 10.5 & 3.9 & 13.2 & 1.3 \\
\hline Rockies & 0.8 & 0 & 11.9 & 5.6 & 19 & 13.5 & 15.9 & 17.5 & 7.1 & 8.7 \\
\hline Southern Rockies & 0 & 0 & 0 & 3.1 & 12.5 & 9.4 & 9.4 & 9.4 & 12.5 & 43.8 \\
\hline Northern Foothills & 0 & 0 & 0 & 0 & 7.1 & 14.3 & 7.1 & 21.4 & 28.6 & 21.4 \\
\hline Aspen Parkland & 0 & 0 & 5.9 & 0 & 5.9 & 11.8 & 5.9 & 5.9 & 41.2 & 23.5 \\
\hline Grasslands & 5.3 & 0 & 0 & 0 & 57.9 & 0 & 0 & 0 & 26.3 & 10.5 \\
\hline Others & 0 & 0 & 0 & 0 & 0 & 100 & 0 & 0 & 0 & 0 \\
\hline
\end{tabular}


Table 4. Summary of the results of the db-RDA of Alberta moss distributions and environmental variables.

\begin{tabular}{|l|c|c|c|}
\hline Statistic & Axis 1 & Axis 2 & Axis 3 \\
\hline Eigenvalues & 0.219 & 0.139 & 0.080 \\
\hline \% Explained variation (cumulative) & 21.9 & 35.8 & 43.8 \\
\hline Pseudo-canonical correlation & 0.921 & 0.802 & 0.775 \\
\hline \% Explained fitted variation (cumulative) & 43.80 & 71.70 & 87.7 \\
\hline
\end{tabular}


Table 5. Db-RDA intra-set correlations of environmental variables and ordination axes. Names in parentheses following each variable are the abbreviations used in db-RDA Figures 9 and 10. Single asterisks indicate significance at $p<0.05$; two asterisks indicate significance at $p<0.01$; three asterisks indicate significance at $p<0.001$.

\begin{tabular}{|l|l|l|l|}
\hline & \multicolumn{2}{c|}{ Intra-set correlations } \\
\hline \multicolumn{1}{|c|}{ Variable (abbreviation) } & Axis 1 & Axis 2 & Axis 3 \\
\hline Total annual snowfall (Snow) & -0.363 & 0.365 & $0.547^{* *}$ \\
\hline Total annual rainfall (Rain) & 0.034 & $0.723^{* * *}$ & 0.216 \\
\hline Mean annual temperature (MAT) & $0.813^{* * *}$ & 0.353 & 0.183 \\
\hline Mean elevation (Elevation) & $0.543^{* *}$ & $0.398^{*}$ & $0.543^{* *}$ \\
\hline Growing degree days above $0^{\circ} \mathrm{C}$ (GDD0) & $0.849^{* * *}$ & -0.021 & 0.069 \\
\hline Mountain landscape (Mountain) & 0.123 & $0.626^{* * *}$ & $0.714^{* * *}$ \\
\hline Plains landscape (Plain) & 0.010 & -0.122 & $-0.665^{* * *}$ \\
\hline
\end{tabular}


List of Figures

Figure 1. Moss collection sites in Alberta used for the analysis. Ecoregions are depicted as polygons in the province (refer to Figure 2). Open circles are collections made in 1997 or earlier; filled circles are collections made after 1997.

Figure 2. Ecozones and ecoregions of Alberta (modified from Ecological Stratification Working Group 1996, with permission from the Canadian Soil Information Service).

Figure 3. Numbers of rare and common species in different numbers of ecoregions.

Figure 4. Percentage of rare and common species in the five floristic affinities. The percentages indicated by each bar represent the proportion of the total species for either the rare or common mosses.

Figure 5. Numbers of rare and common species in the ecoregion groups (\% of ecoregion group species total is presented above each bar).

Figure 6. Number of common mosses belonging to five floristic affinities in the four ecoregion groups.

Figure 7. Number of rare mosses belonging to five floristic affinities in the four ecoregion groups.

Figure 8. Numbers of rare and common species belonging to the 11 species distributional elements.

Figure 9. Ratio of rare to common (R/C) species for each of the 11 species distributional elements.

Figure 10. db-RDA biplot ordination of axis1 and axis 2 showing the vectors of significant environmental variables and ecoregions. Plot symbols indicate ecoregion groups: black circles Prairies; diamonds - Mountains \& Foothills; squares - Northern Boreal; $X^{\prime}$ s - Central Boreal.

Figure 11. db-RDA biplot ordination of axis1 and axis 3 showing the vectors of significant environmental variables and ecoregions. Plot symbols indicate ecoregion groups: black circles Prairies; diamonds - Mountains \& Foothills; squares - Northern Boreal; $X^{\prime}$ s - Central Boreal.

Figure 12. db-RDA biplot ordination of axis1 and axis 2 showing the vectors of significant environmental variables and centroids of common and rare species. Rare mosses are indicated by black circles; common mosses are indicated by crosses. Ecoregions (open circles) and vectors as per Figure 10. 


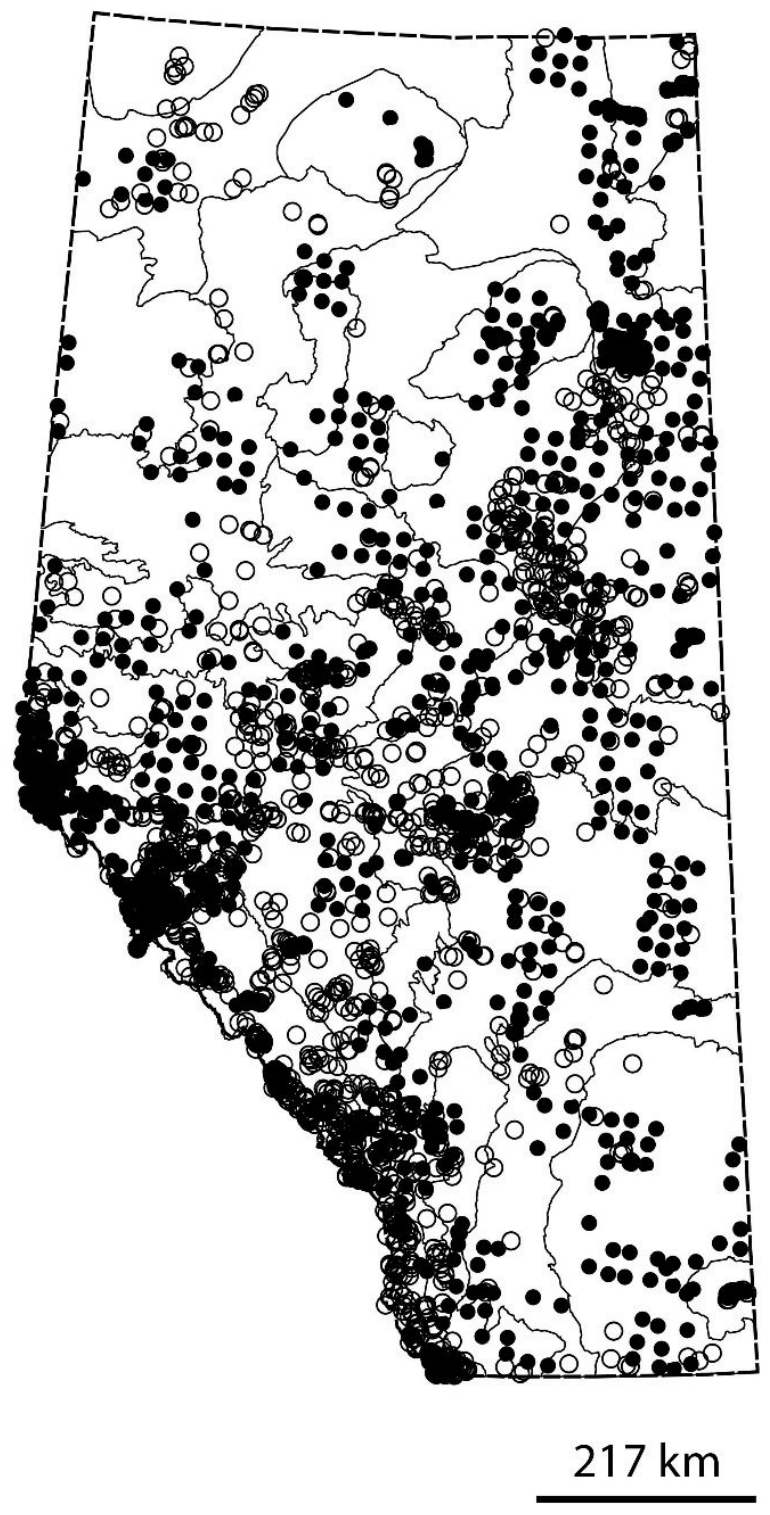

Figure 1. Moss collection sites in Alberta used for the analysis. Ecoregions are depicted as polygons in the province (refer to Figure 2). Open circles are collections made in 1997 or earlier; filled circles are collections made after 1997. 


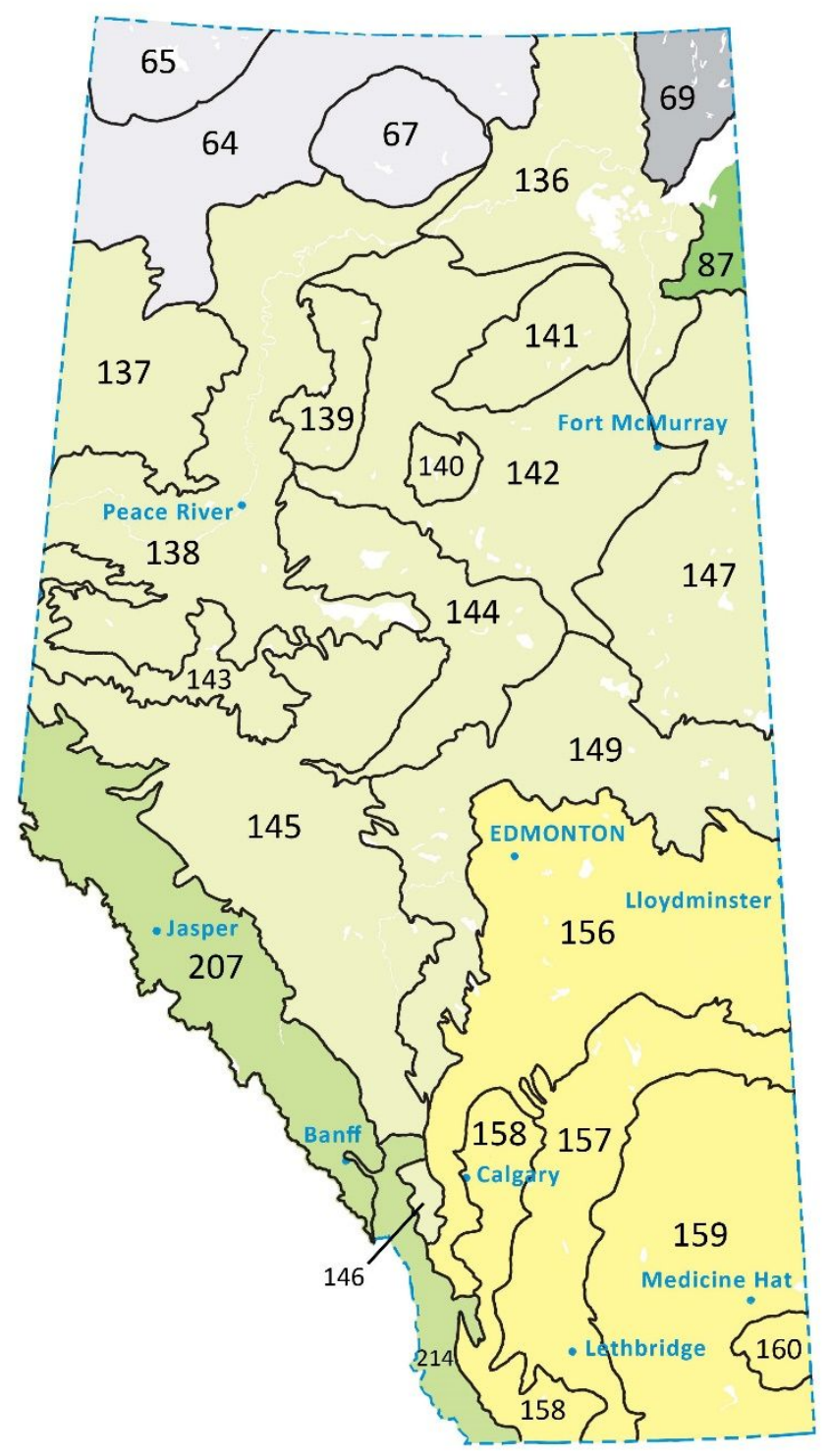

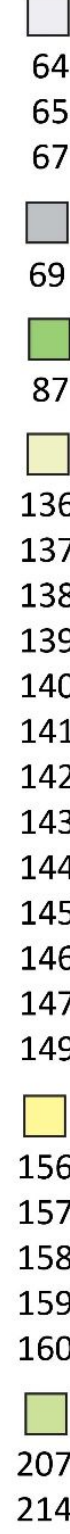

\section{Taiga Plains Ecozone}

Hay River Lowland Northern Alberta Uplands Northern Alberta Uplands

\section{Taiga Shield Ecozone}

Tazin Lake Upland

\section{Boreal Shield Ecozone} Athabasca Plain

\section{Boreal Plains Ecozone}

Slave River Lowland

Clear Hills Upland

Peace Lowland

Mid-Boreal Uplands

Mid-Boreal Uplands

Mid-Boreal Uplands

Wabasca Lowland

Western Boreal

Mid-Boreal Uplands

Western Alberta Upland

Western Alberta Upland

Mid-Boreal Uplands

Boreal Transition

\section{Prairies Ecozone}

Aspen Parkland

Moist Mixed Grassland

Fescue Grassland

Mixed Grassland

Cypress Upland

Montane Cordillera Ecozone

Eastern Continental Ranges

Northern Continental Divide

Figure 2. Ecozones and ecoregions of Alberta (modified from Ecological Stratification Working Group 1996, with permission from the Canadian Soil Information Service). 


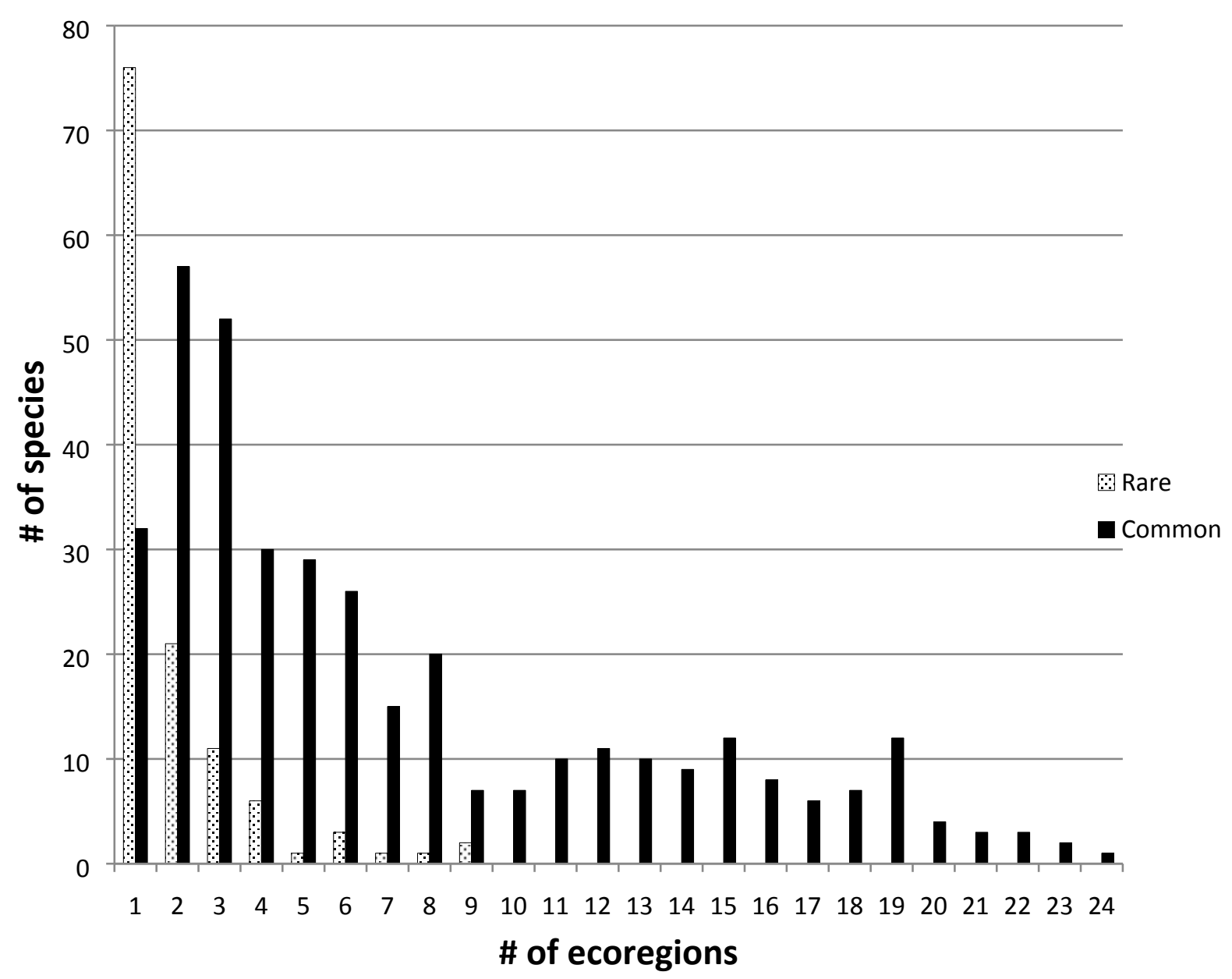

Figure 3. Numbers of rare and common species in different numbers of ecoregions. 


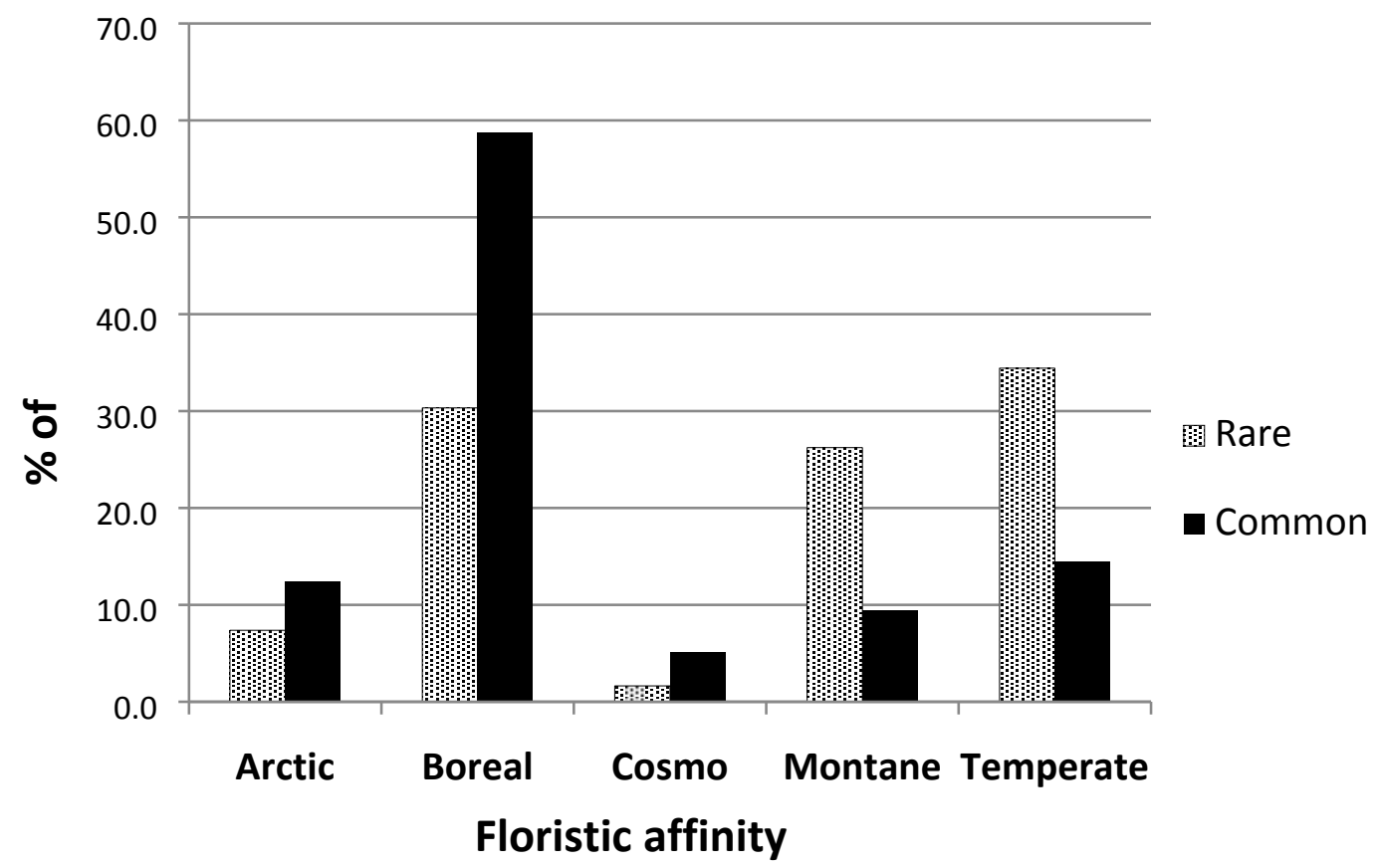

Figure 4. Percentage of rare and common species in the five floristic affinities. The percentages indicated by each bar represent the proportion of the total species for either the rare or common mosses. 


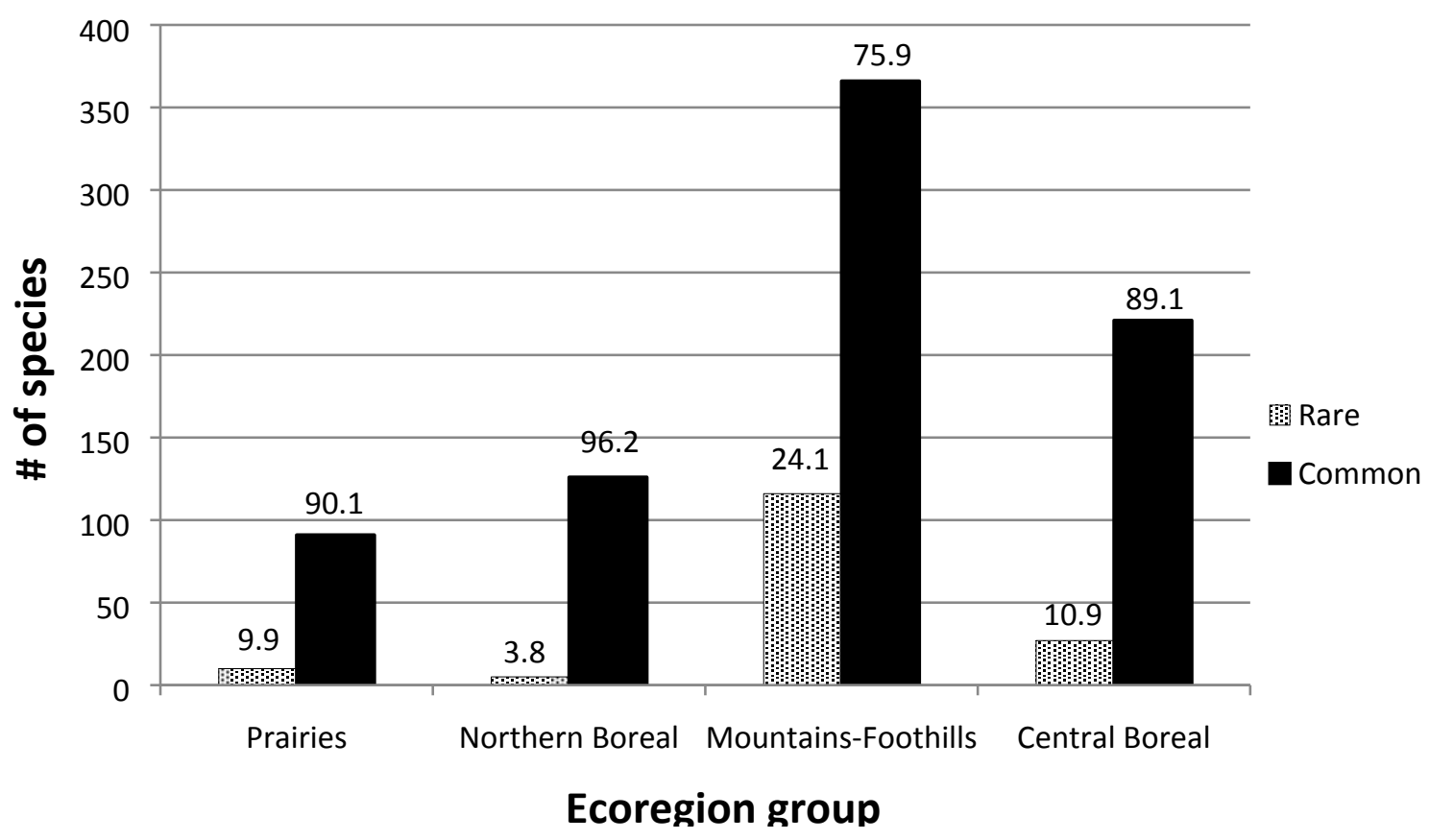

Figure 5. Numbers of rare and common species in the ecoregion groups (\% of ecoregion group species total is presented above each bar). 


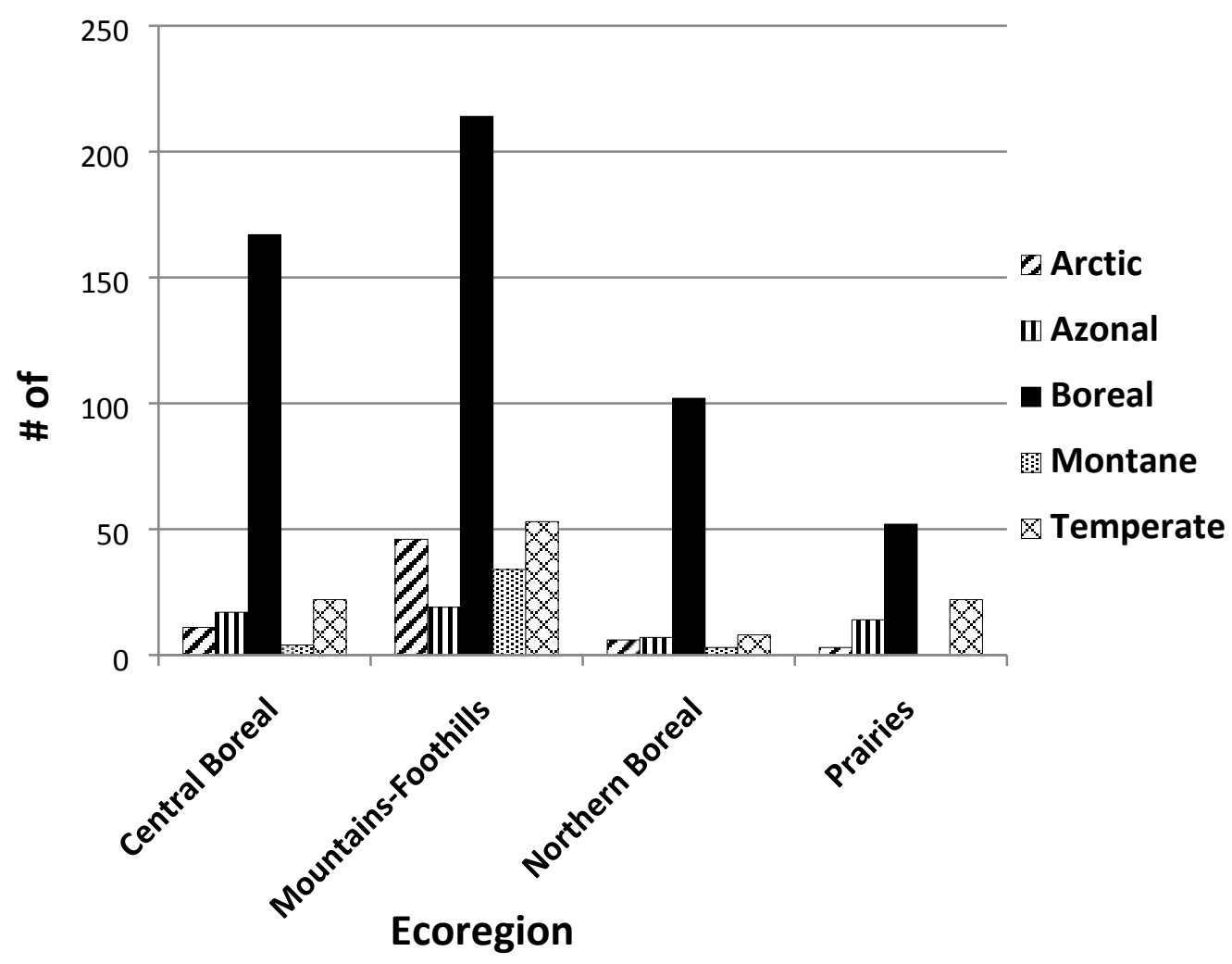

Figure 6. Number of common mosses belonging to five floristic affinities in the four ecoregion groups. 


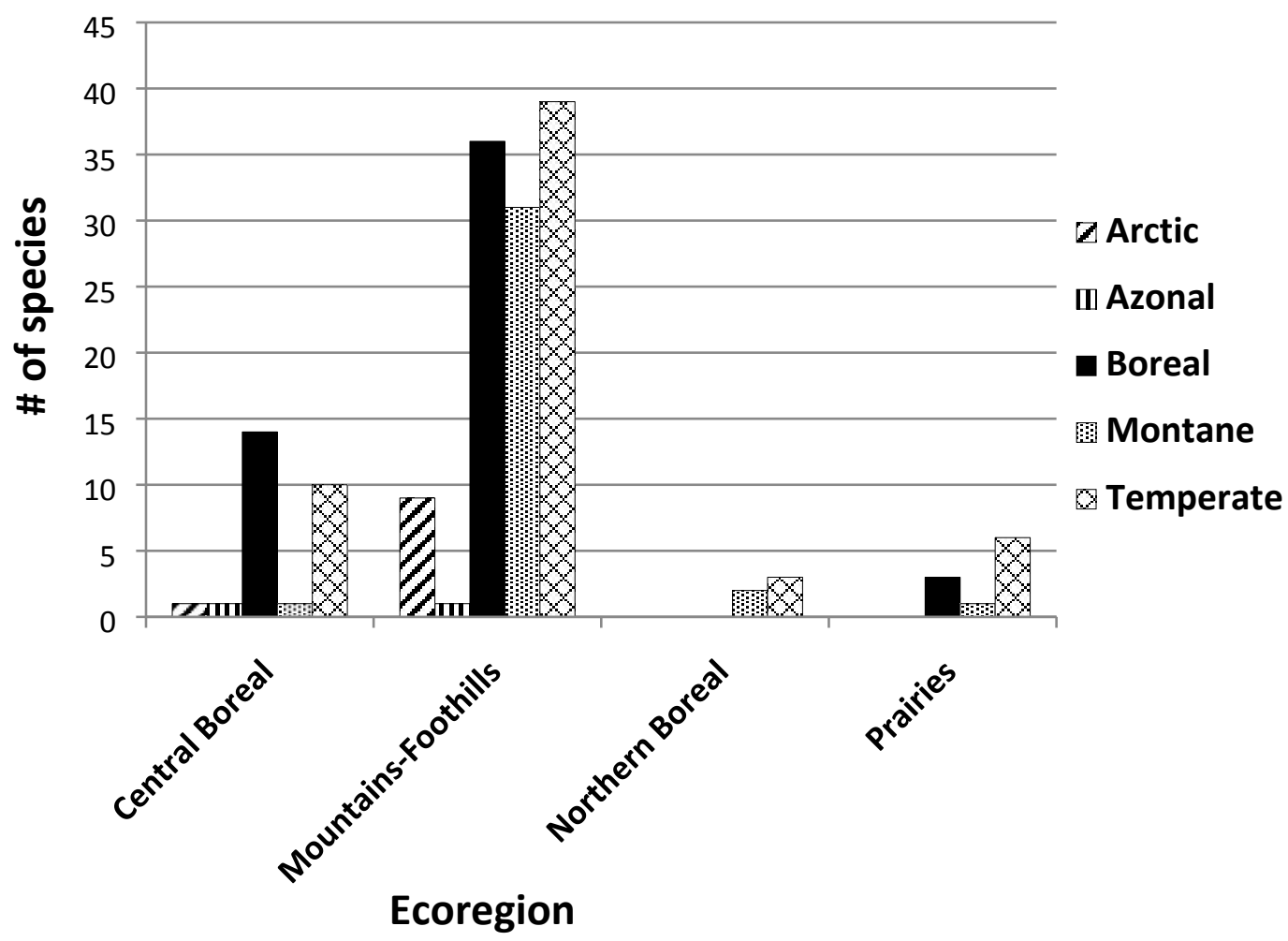

Figure 7. Number of rare mosses belonging to five floristic affinities in the four ecoregion groups. 


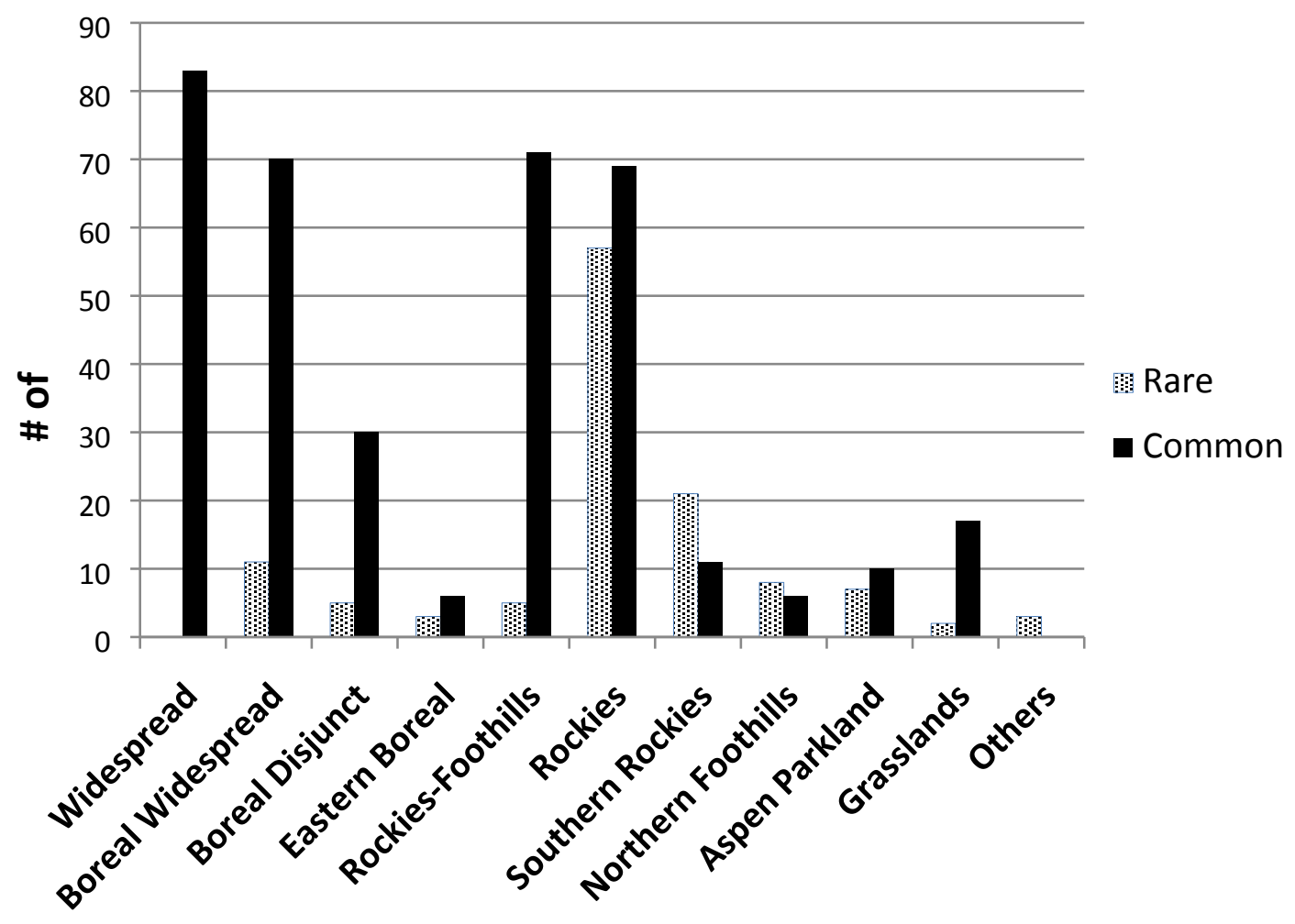

Figure 8 . Numbers of rare and common species belonging to the 11 species distributional elements. 


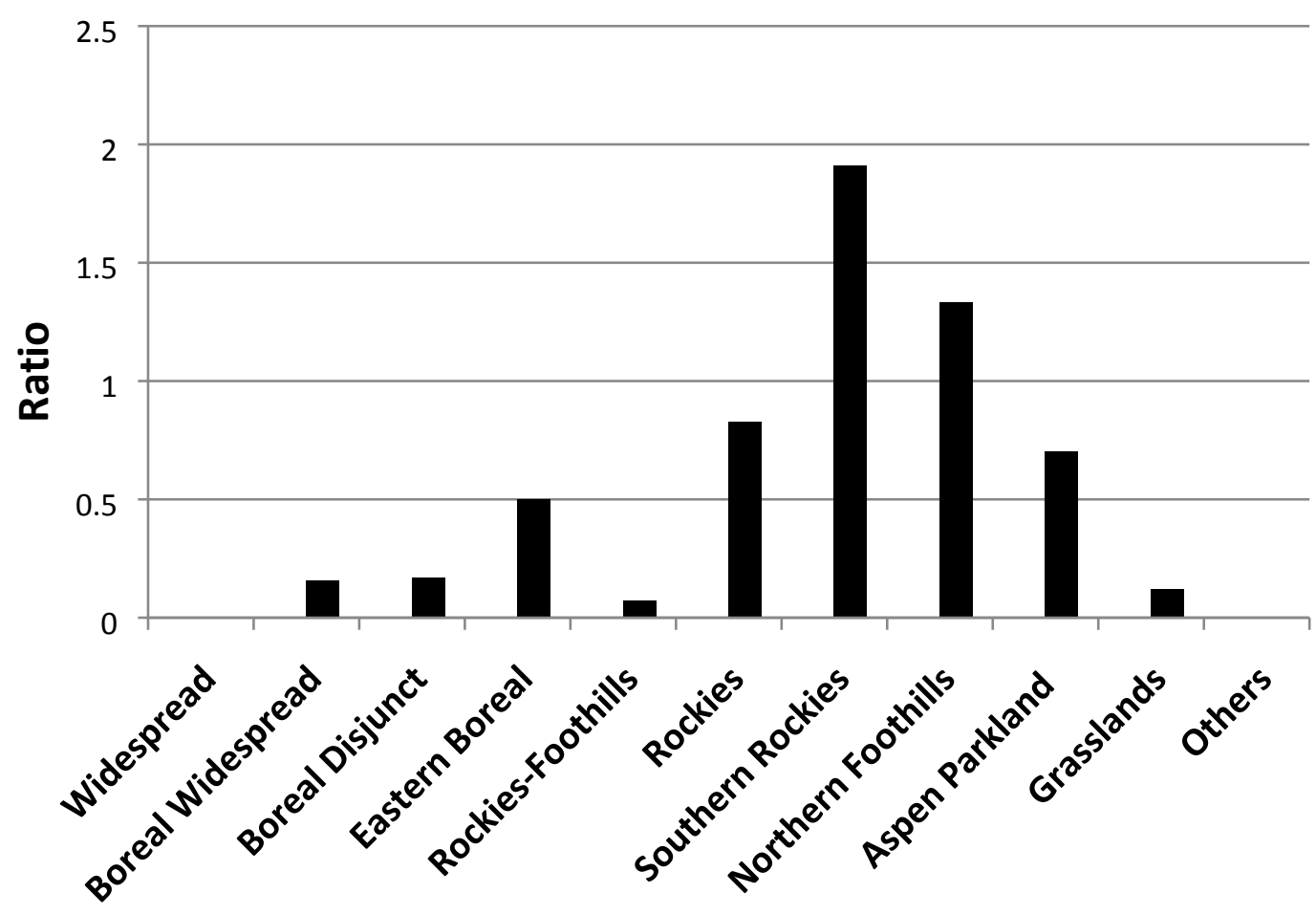

Figure 9. Ratio of rare to common $(\mathrm{R} / \mathrm{C})$ species for each of the 11 species distributional elements. 


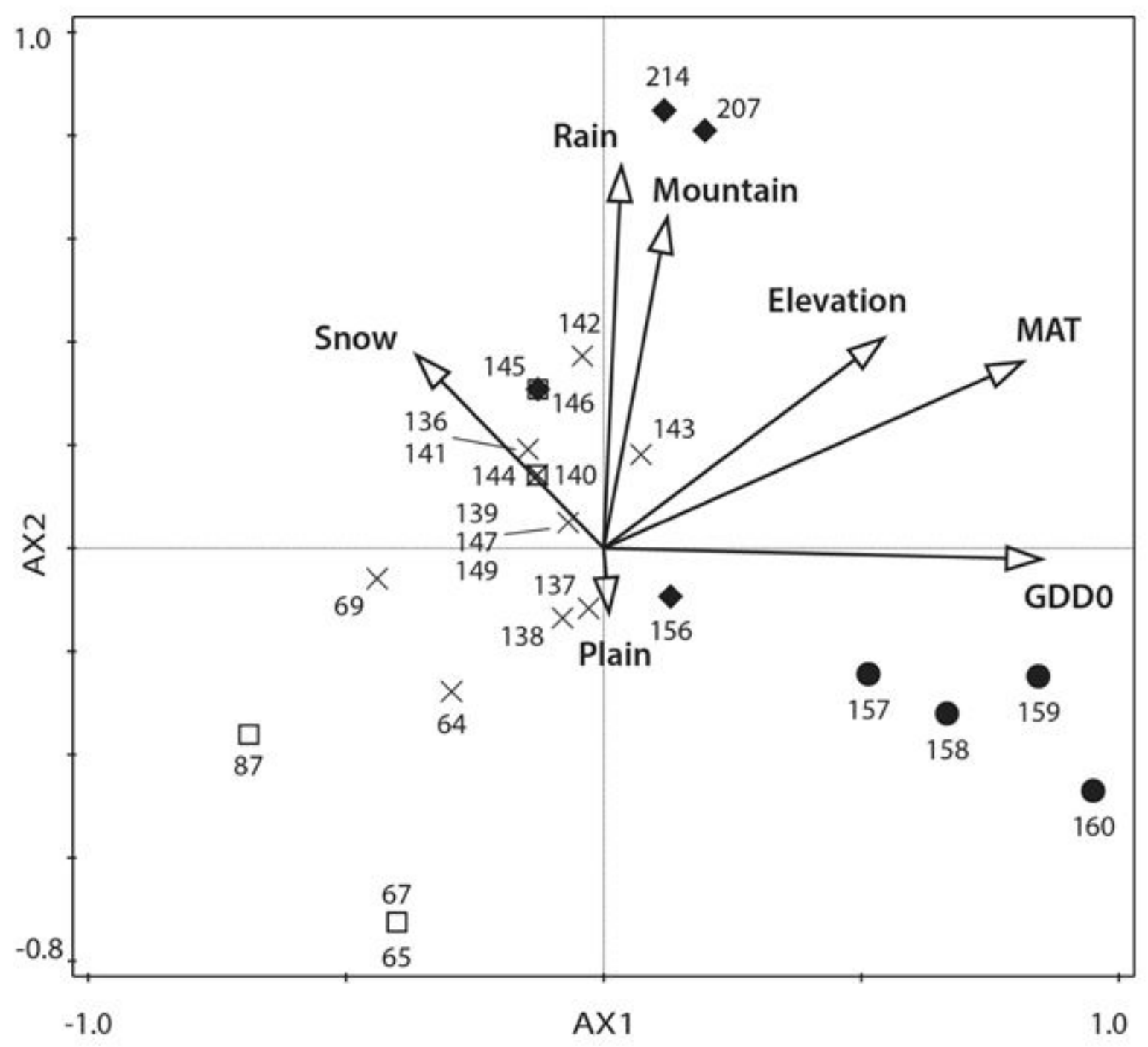

Figure 10. db-RDA biplot ordination of axis1 and axis 2 showing the vectors of significant environmental variables and ecoregions. Plot symbols indicate ecoregion groups: black circles Prairies; diamonds - Mountains \& Foothills; squares - Northern Boreal; $X^{\prime}$ s - Central Boreal. 


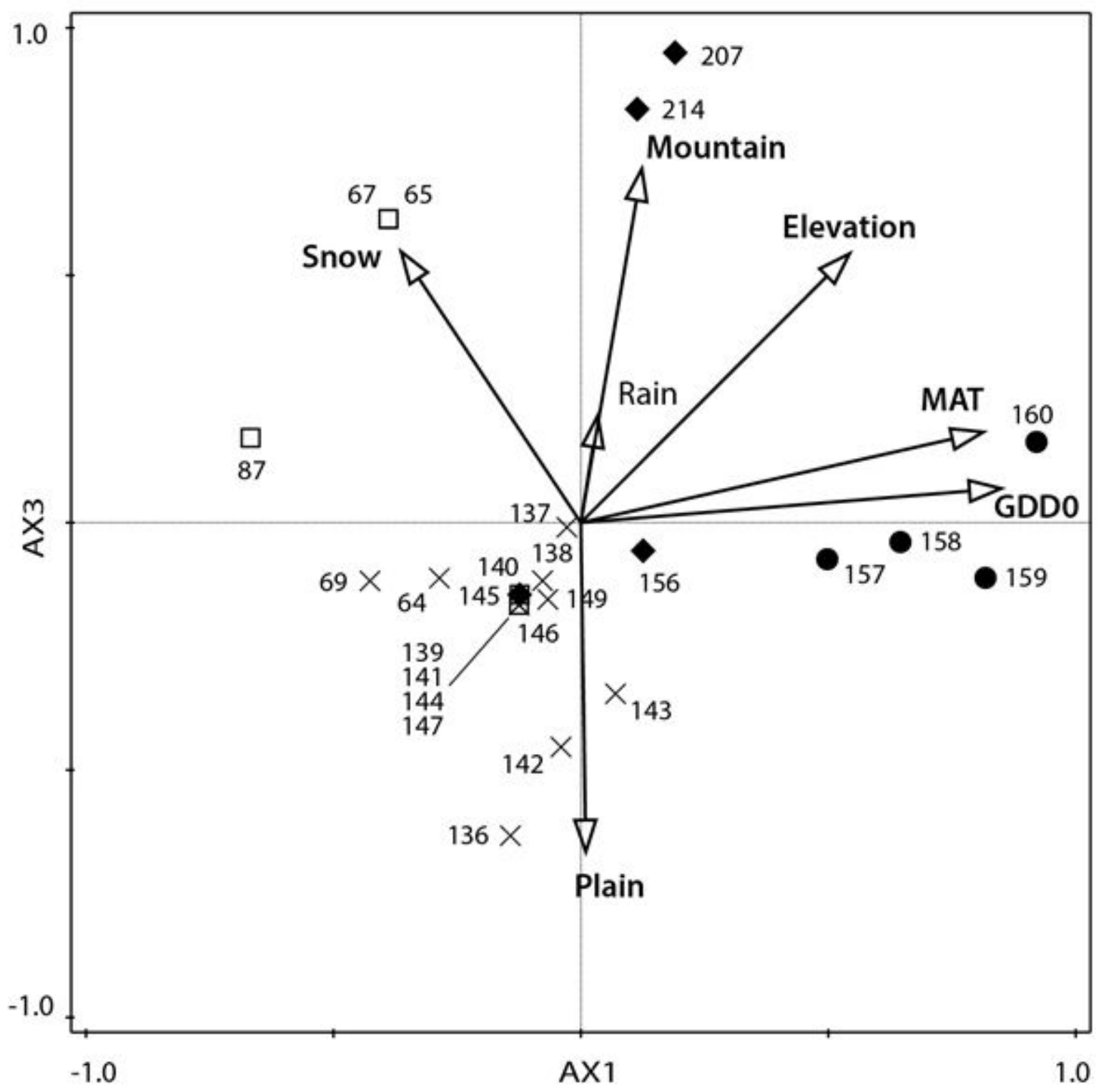

Figure 11. db-RDA biplot ordination of axis1 and axis 3 showing the vectors of significant environmental variables and ecoregions. Plot symbols indicate ecoregion groups: black circles Prairies; diamonds - Mountains \& Foothills; squares - Northern Boreal; $X^{\prime}$ ' - Central Boreal. 


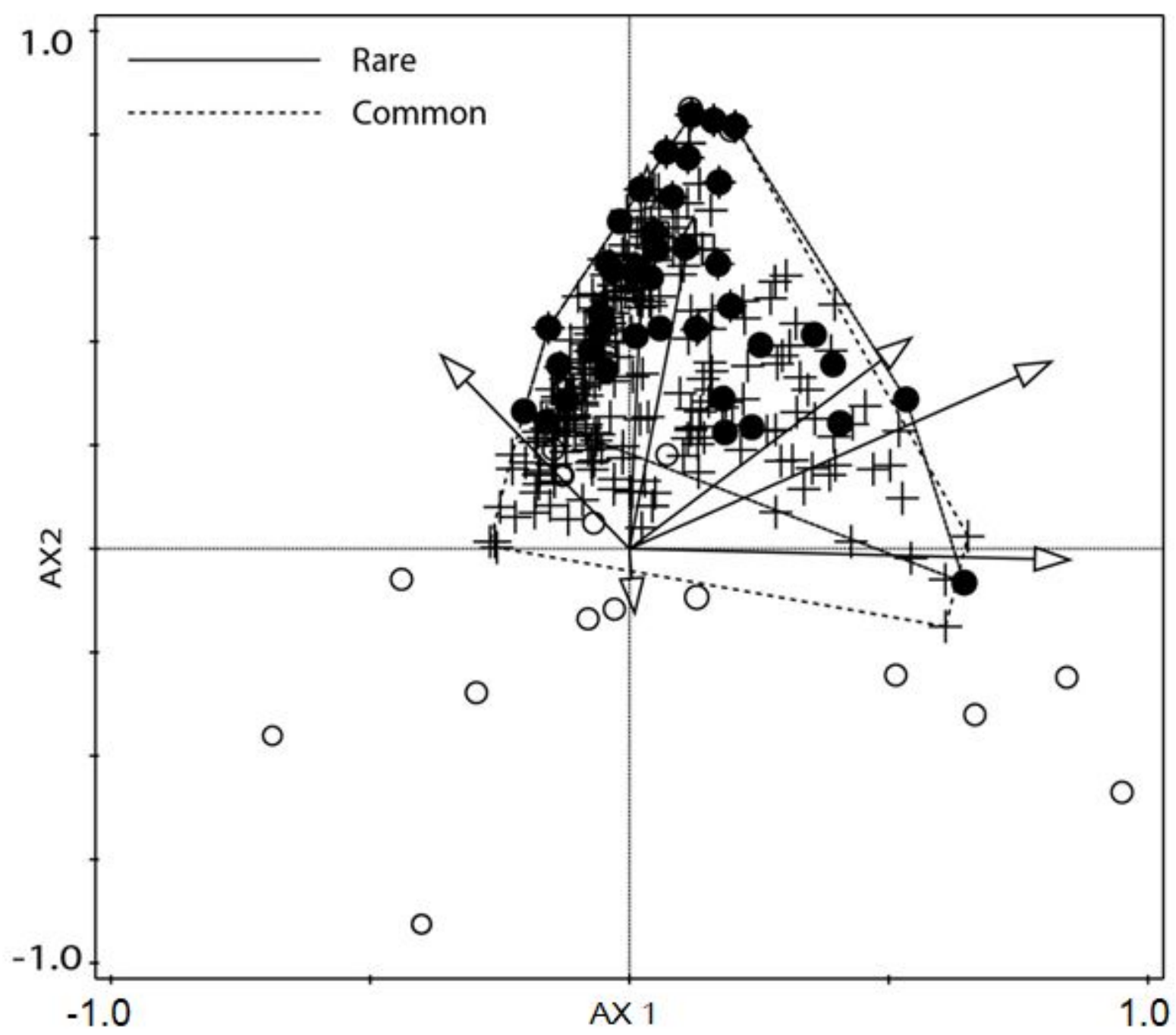

Figure 12. db-RDA biplot ordination of axis 1 and axis 2 showing the vectors of significant environmental variables and centroids of common and rare species. Rare mosses are indicated by black circles; common mosses are indicated by crosses. Ecoregions (open circles) and vectors as per Figure 10. 
